
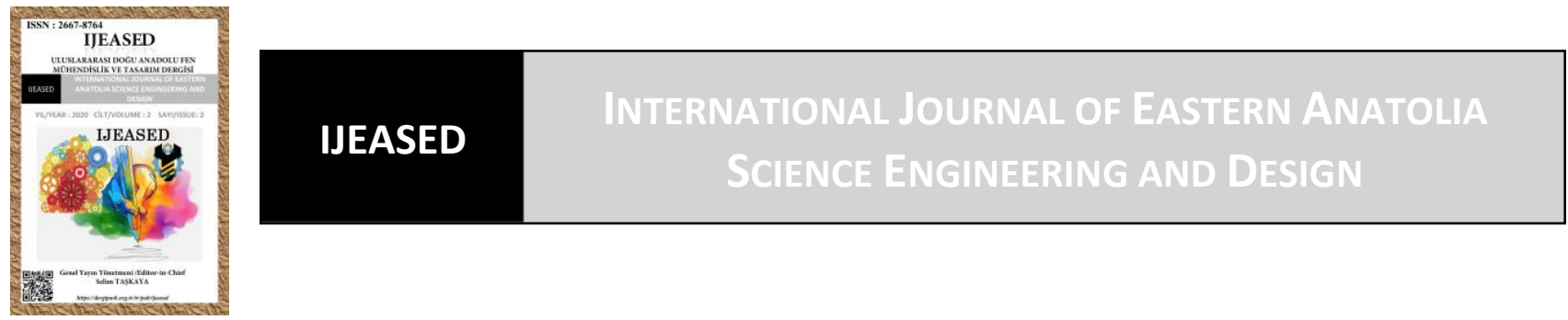

\author{
Uluslararası Doğu Anadolu Fen Mühendislik ve Tasarım Dergisi \\ ISSN: 2667-8764, 2(2), 169-189, 2020 \\ https://dergipark.org.tr/tr/pub/ijeased
}

Araştırma Makalesi / Research Article

Doi: 10.47898 /ijeased.767676

\title{
Bazı Fungisitlerin Şeker Pancarı Kök Çürüklüğü ve Çökerten Etmeni Rhizoctonia solani’ ye Karşı Etkileri
}

\author{
Meltem AVAN ${ }^{1, a^{*}}$, Yakup Zekai KATIRCIOĞLU ${ }^{1, b}$ \\ 1,a Ankara Universitesi, Ziraat Fakültesi, Bitki Koruma Bölümü, 06110, Türkiye. \\ 1,b Ankara Universitesi, Ziraat Fakültesi, Bitki Koruma Bölümü, 06110, Türkiye.

\begin{tabular}{l|l|l}
\hline \multicolumn{1}{c|}{ Yazar Kimliği / Author ID (ORCID Number) } & \multicolumn{1}{|c}{ Makale Süreci / Article Process } \\
\hline "Sorumlu Yazar / Corresponding author : & Geliş Tarihi / Received Date $:$ & 10.07 .2020 \\
meltem_avn@ hotmail.com & Revizyon Tarihi / Revision Date : & 30.07 .2020 \\
\hline iD https://orcid.org/0000-0002-2939-8177, M. Avan & Kabul Tarihi / Accepted Date : & 16.08 .2020 \\
iD https://orcid.org/0000-0001-5308-9414, Y.Z.Katırcioğlu & Yayım Tarihi/Published Date : & 15.12 .2020 \\
\hline
\end{tabular}

Alıntı /Cite : Avan, M., Katırcıoğlu, Y.Z. (2020). Bazı Fungisitlerin Şeker Pancarı Kök Çürüklüğü ve Çökerten Etmeni Rhizoctonia solani’ye Karşı Etkileri, Uluslararası Doğu Anadolu Fen Mühendislik ve Tasarım Dergisi, 2(2), 169-189.

\begin{abstract}
Özet
Konya bölgesi ülkemizde şeker pancarı üretiminin 1/3' ünden fazlasını elinde tutan oldukça önemli bir şeker pancarı üretim alanıdır. 2015-2017 yılları arasında bu bölgede 866 tarlada yapılan surveyler sonucu 691'inde özellikle hasata yakın geç dönemde ve tüm dönemlerde kök çürüklükleri tespit edilmiş, bunlar arasında da en çok Rhizoctonia etmenine rastlandığı bildirilmiştir. Yapılan morfolojik tanılama, izolasyon, mikroskopik gözlem, ITS rDNA bölgesinin sekans verileri ile yapılan moleküler yöntemlerle etmen Rhizoctonia spp. olarak tanımlanmıştır. Bazı fungisitlerin patojene etkisini tespit etmek amacıyla yapılan çalışmamızda, elde edilen izolatlardan en yaygın ve virülensliği en fazla olan Rhizoctonia solani AG-2-2-IIIB' ye ait 2G izolatı ile Azoxystrobin, Fludioxonil, Flutolanil, Tolclofos-methly, Pyraclostrobin+Epoxiconazole, Difenoconazole+Propiconazole, Spiroxamine+Prothiocona ve Sedaxane+Fludioxonil+Metalaxyl-M etken maddeli 8 farklı fungisit petri ve saksı denemelerinde kullanılmıştır. Petri misel denemesinde tespit edilen engelleme dozları ile beraber firmaların önerdiği tam doz, çift kat doz, yarı dozlar saksı denemesinde kullanılmıştır. Çalışmalar sonucunda, en etkili fungisit ve dozu olarak Azoxystrobin' un çift kat dozu ve Sedaxane+Fludioxonil+Metalaxyl-M' ın tam dozu olduğu tespit edilirken; saksı çalışmalarında, önerilen dozun 2 katı dozlarının daha etkili bulunması patojenin bu ilaçlara karşı direnç geliştirmiş olmasını düşündürmektedir.
\end{abstract}

Anahtar Kelimeler: Beta vulgaris, Fungisit etkisi, Kök çürüklüğü, Rhizoctonia solani. 


\title{
The Effects of Some Fungicides against Rhizoctonia solani Causing Root Rot and Damping-off on Sugar Beet
}

\begin{abstract}
Konya region is a very important sugar beet production area that contains more than 1/3 of sugar beet production in Turkey. Root rots were detected in 691 of the surveys made in 866 fields in this region between the years 2015-2017, Root rots were detected in the late period close to the harvest period and in all periods, Rhizoctonia has been reported to be the most common among root rot. The causal organism was defined as $R$. spp. by visual diagnosis, isolation, microscopic observation and molecular methods. Sequence data of the ITS rDNA region confirmed the species identity of pathogens as Rhizoctonia. In our study to determine the effect of fungicides on the pathogen; 4 different doses of 8 different fungicides with Azoxystrobin, Fludioxonil, Flutolanil, Tolclofos-methly, Pyraclostrobin + Epoxiconazole, Difenoconazole + Propiconazole, Spiroxamine + Prothioconazole ve Sedaxane + Fludioxonil + Metalaxyl-M were used in petri dish and pot experiments with $2 G$ isolate from Rhizoctonia solani AG-2-2-IIIB which is the most common and most virulent of the isolates obtained. The inhibition doses obtained in the petri mycellium experiment were not found effective in the pot experiment. As a result of studies, as the most effective fungicide and dosage, while it is determined that Azoxystrobin is a double dose and Sedaxane + Fludioxonil + Metalaxyl-M is a full dose; in pots studies, the double dose of the recommended dose is more effective suggests that the pathogen has developed resistance to these fungicides.
\end{abstract}

Keywords: Beta vulgaris, Fungicide effect, Root rot, Rhizoctonia solani.

\section{Giriş}

Şeker pancarı (Beta vulgaris L.) köklerinde çok miktarda şeker bulunan, sıcak iklimlerde üretimi yapılan, stratejik önemi olan, dikotiledon ticari bir endüstri bitkisidir (Draycott, 2006; Alfaig, 2011). Türkiye, dünyada Fransa, Rusya, ABD ve Almanya’ dan sonra üretimde 5. sira ile önemli bir yer almaktadır (FAOSTAT, 2019). Konya ili de yaklaşık 6 milyon ton ile Türkiye' de şeker pancarı üretiminin \% 30’ unu elinde tutan önemli bir bölgedir (TÜİK, 2019).

Rhizoctonia solani Kühn dünya çapında ekonomik olarak önem taşıyan birçok konukçusu olan toprak kökenli önemli bir patojendir (Anderson, 1982; Ogoshi, 1987). Rhizoctonia fungusu genetik özellikleri açısından değişik anastomosis gruplarına ve alt gruplarına ayrılmakta olup (Ogoshi, 1987) şimdiye dek 13 anastomosis grubu tespit edilmiştir (Sneh ve ark., 1991). Anastomosis gruplar arasındaki hifsel uyuşmazlıklar ya da kaynaşmalar $R$. solani izolatlarının sınıflandırılmasında kullanılmaktadır (Sneh ve ark., 1991). $R$. solani' nin en önemli ve en yıkıcı etkiye sahip olan grubu AG-2-2-IIIB' dir (Engelkes ve Windels, 1996). Bu grup fasulye, soya fasulyesi, pirinç, mısır gibi ürünlerde zarar yapsa da en çok şeker pancarında hastalığa neden olmaktadır (Buhre ve ark., 2009; Harveson ve ark., 2009). Patojen şeker pancarında kök ve kök boğazı çürüklügüne, çökertene, yaprak ve gövde yanıklıklarına neden olmaktadır (Carling ve ark., 1994). 
Hastalık ile mücadelede dayanıklı çeşit kullanımı (Panella ve ark., 1995; Büttner ve ark., 2004), ürün rotasyonu (Harveson, 2008; Buhre ve ark., 2009), uygun ve doğru zamanda uygulanan fungisit kullanımı ile (Windels ve Brantner, 2005; Harveson, 2008) entegre mücadelede etkili çözüm kaynakları olarak öne sürülmüştür. Şeker pancarında hastalık yapan Rhizoctonia AG-2-2IIIB grubuna ait patojenler için yapılan çalışmalara göre bazı araştırıcılar azoxystrobin ve prothioconazole' un (Khan ve ark., 2009), bazıları flutolanil ve azoxystrobin' in (Bolton ve ark., 2010) etkili olduğunu bildirmişlerdir. Fakat son zamanlarda artan fungisit direnci ve bazı çevresel faktörler sebebiyle hastalıkla mücadelede fungisit yerine başka alternatifleri bulmaya odaklanmişlardır (Larkin ve ark., 1998).

Çalışmamızda bazı fungisitlerin şeker pancarı kök çürüklügü ve çökerten etmeni $R$. solani’ ye karşı etkilerini tespit etmek amacıyla 8 ayrı fungisit ile izolatlar arasında en yaygın olarak tespit edilen multinükleat $R$. solani AG-2-2-IIIB izolatlarından en yüksek virülensli izolatı ve hassas şeker pancarı çeşiti olan Aranka kullanılmıştır. Çalışmada patojenin petride misel gelişimi denemeleri ve kontrollü şartlarda iklim odası saksı denemeleri yapılmıştır.

Denemeler sonucunda, 8 farklı fungisitin bu patojene karşı etkileri değerlendirilerek, elde edilen sonuçlarla patojene karşı etkili kimyasal mücadele yöntemlerini tespit ederek, entegre mücadele çalışmaları içerisinde alternatif bir seçenek olmayı amaçlanmıştır.

\section{Materyal ve Metot}

Surveyler sonucu toplanan örneklerden elde edilen izolatların moleküler çalışmaları sonucunda 71 adet Rhizoctonia izolatlarından 61 tanesi multinükleat (MN) Rhizoctonia solani, 10 tanesi de binükleat $(\mathrm{BN}) R$. spp. olarak tespit edilmiş, MN $R$. solani izolatlarından AG-2-2-IIIB, AG-4-HGI, AG-4-HGII, AG-4-HGIII, AG-5 ve AG-11 anastomosis grubuna ait izolatlar elde edilmiştir. Bunlar arasında en yaygın görülen anastomosis grup 33 adet AG-2-2-IIIB izolatları olarak tespit edilirken, bu grubu takiben 17 adet AG-4-HGI, 8 adet AG-4-HGII, 1 adet AG-4-HGIII, 1 adet AG-5, 1 adet AG-11 izolatı temin edilmiştir. 10 adet BN R. spp. izolatlarından ise 3 adet AGA, 7 adet AG-K anastomosis gruba ait bulunmuştur. Rhizoctonia' ya karşı ilaç etkinlik denemeleri için en yaygın tespit edilen AG-2-2-IIIB izolatının en virülent izolatlarından biri olan 2G izolatı ile Azoxystrobin, Fludioxonil, Flutolanil, Tolclofos-methly, Pyraclostrobin + Epoxiconazole, Difenoconazole + Propiconazole, Spiroxamine + Prothioconazole ve Sedaxane + Fludioxonil + Metalaxyl-M etken maddeli fungisitler petri misel gelişiminde ve saksı denemelerinde kullanılırken; 
saksı denemelerinde ise bu fungisitlerin tavsiye edilen tam dozu, çift kat dozu, yarı dozu ile petri misel gelişimi denemelerinde tespiti yapılan engelleme dozları kullanılmıştır (Tablo 1).

Tablo 1. Firmaların Rhizoctonia’ ya ve/veya kök çürüklüklerine karşı tavsiye edilen tohum ilaçları ve dozları ( $\mathrm{ml} / \mathrm{mg} / \mathrm{kg}$ tohum)

\begin{tabular}{lll}
\hline Etken Madde & Dozu & Firmalar ve Kullanılan Fungisitleri \\
\hline Azoxystrobin & $1.5 \mathrm{ml}$ & Agrobest (Rotundis) \\
\hline Tolclofos-methyl & $0.6 \mathrm{ml}$ & Sumiagro (Rizolex) \\
\hline Fludioxonil & $0.2 \mathrm{ml}$ & Syngenta (Celest max 100FS) \\
\hline Flutolanil & $0.175 \mathrm{mg}$ & AMC (Moncut 40 SC) \\
\hline Spiroxamine+Prothioconazole & $1.02 \mathrm{ml}$ & Bayer (İnput) \\
\hline Difenoconazole+Propiconazole & $0.3 \mathrm{ml}$ & Syngenta (Armure 300 EC) \\
\hline Pyraclostrobin+Epoxiconazole & $1.54 \mathrm{ml}$ & Agrobest (Roscana) \\
\hline Sedaxane+ Fludioxonil + Metalaxyl-M & $30.2 \mathrm{ml}$ & Syngenta (Vibrance) \\
\hline
\end{tabular}

\subsection{Bazı Fungisitlerin Rhizoctonia solani Misel Gelişimine Etkilerinin Belirlenmesi}

Denemede 8 ayrı fungisitin hedeflenen her dozu ayrı ayrı olacak şekilde 100 ml' lik PDA ortamı hazırlanmış ve otoklavda $121{ }^{\circ} \mathrm{C}$ ' de $20 \mathrm{dk}$ steril edildikten sonra bu ortamlar $40-45{ }^{\circ} \mathrm{C}$ ' ye kadar soğutulmuştur. Hazırlanan 100 ml' lik ortamların içerisine 8 ayrı aktif maddeyi içeren ticari fungisitlerin kg tohuma karşı önerilen dozları, yarı güçlü PDA ortamının litresine göre aynı oranlarda olacak şekilde tam ve alt üst dozları hesaplanarak hazırlanmıştır. Çalışmada çift kat doz, tam doz, yarı doz, 1/50 doz ve 1/100 dozları kullanılmış olup, Azoxystrobinde 5 kat, 10 kat ve 100 kat doz, Fludioxonil' de 1/1000, 1/2000 ve 1/5000 kat doz, Tolclofos-methyl' de 1/1000 kat doz, Pyraclostrobin + Epoxiconazole' de 1/1000 kat doz, Spiroxamine+Prothioconazole' de 1/1000 kat doz, Sedaxane+Fludioxonil +Metalaxy-M' de 1/1000, 1/2000 ve 1/5000 kat dozları da engelleme dozlarını bulmak amacıyla kullanılmıştır. Hazırlanan bu dozlara ait ortamlar steril petrilere 5 tekerrür olacak şekilde dökülmüştür (Şekil 1b). Bu şekilde hazırlanan ortamların tam ortasına $5 \mathrm{~mm}$ çapındaki fungusun aktif gelişen miselyumlarını içeren agar yerleştirilerek (Şekil 1a), hazırlanan petri kapları, $24 \pm 1{ }^{\circ} \mathrm{C}^{\prime}$ de 12 saat aydınlık, 12 saat karanlıkta inkübe edilmiştir. Kontrol petrilerinde kolonilerdeki miseller petri kenarına kadar kapladığında, tüm petrilerdeki koloni çapları farklı iki yönde ölçülerek kaydedilmiştir (Şekil 1c). 


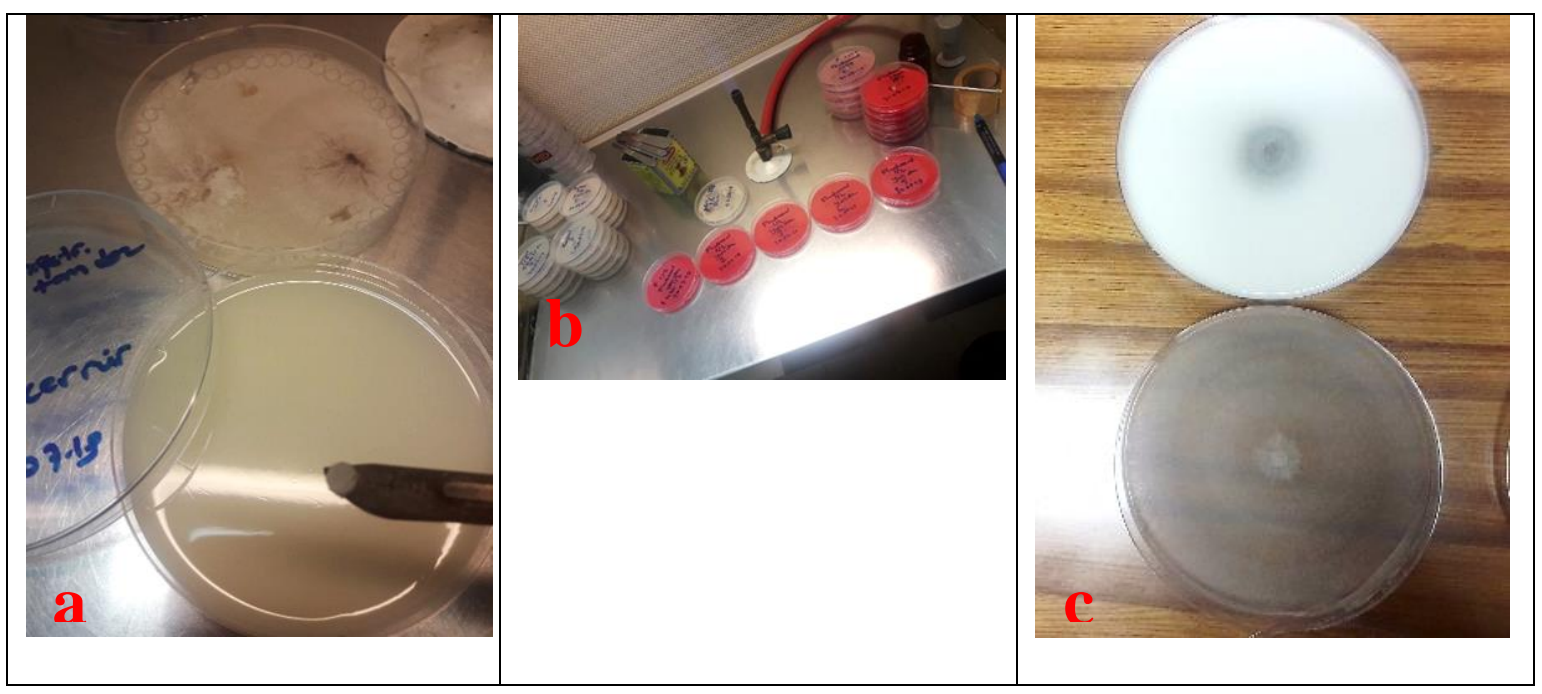

Şekil 1. Fungisitlerin misel gelişimi denemeleri için yapılan hazırlıklar

Fungisitlerin miselyal gelişimine etkisi ile ilgili çalışmalardan elde edilen veriler MINITAB paket programı kullanılarak regresyon analizine tabi tutularak, fungisitlerin engelleme dozları belirlenmiştir.

\section{2. İklim Odasında Rhizoctonia solani İzolatına Karşı İlaç Etkinliklerinin Belirlenmesi}

Denemeler kontrollü şartlarda iklim odasında 1:1:1 bahçe toprağı, kum ve yanmış çiftlik gübresi karışımının konulduğu saksılarda yapılmıştır. Rhizoctonia izolatları, inokulum tabakası tekniği (inoculum layer technique) kullanılarak saksıya transfer edilmiştir (Herr ve ark., 1980, Schmitthenner ve ark., 1962). Bu teknikle steril saksıların 2/3' üne bu toprak karışımı doldurulmuştur. Ardından petrilerde geliştirilen Rhizoctonia izolatları disk şeklinde toprağın üst kısmına yerleştirilip, üzerlerine saksı başına 10 adet invitro (Petri denemesi)' da etkili bulunan dozlarla ve firmaların tavsiye ettiği fungisitlerin tam dozları, yarı dozları ve çift kat dozları ile ilaçlanan tohumlar yerleştirilmiştir (Şekil 2a, c) ve deneme 4 tekerrürlü olacak şekilde gerçekleştirilmiştir (Şekil 2b). Yerleştirilen tohumların üzerleri hazırlanan steril toprak karışımı ile kapatılmıştır. Saksılar sulandıktan sonra $24 \pm 2{ }^{\circ} \mathrm{C}^{\prime}$ de 12 saat aydınlık 12 saat karanlık koşullarda inkübe edilmiştir. Bu süre içerisinde düzenli sulama yapılmıştır. Bitkilerin çıkışından itibaren çıkan bitkiler ve çıkış sonrası ölen bitkiler kaydedilerek, son değerlendirme ise 6 . haftanın sonunda kalan bitkiler sökülerek aşağıdaki 0-4 skalasına göre değerlendirilmiştir (Hanson, 2006) (Tablo 2). 
Tablo 2. Hanson (2006) 0-4 hastalık skalas1

\begin{tabular}{lc}
\hline Değerlendirme & Skala Değeri \\
\hline Hiç leke olmayan sağlıklı bitki & 0 \\
\hline Hafif gelişme geriliği ve yapraklarda solgunluk & 1 \\
\hline Klorotik yapraklar mevcut ve yaprak kenarlarında nekrozlu görünüm & 2 \\
\hline Kök kısımlarında kuruma, kahverengileşme, yapraklarda ölüm & 3 \\
\hline Ölmüş bitki & 4 \\
\hline
\end{tabular}

Elde edilen verilerden Towsend-Heuberger formülü kullanılarak hastalık yüzdeleri hesaplanmıştır.

Towsend-Heuberger formülü:

Hastalık Yüzdesi: $\quad \underline{\Sigma(\text { değer alan bitki sayısı X sınıf değeri) }}$

En yüksek skala değeri $\mathrm{X}$ toplam bitki sayısı

Bu şekilde izolatların neden olduğu bitkilerdeki hastalık yüzdeleri belirlenmiştir.

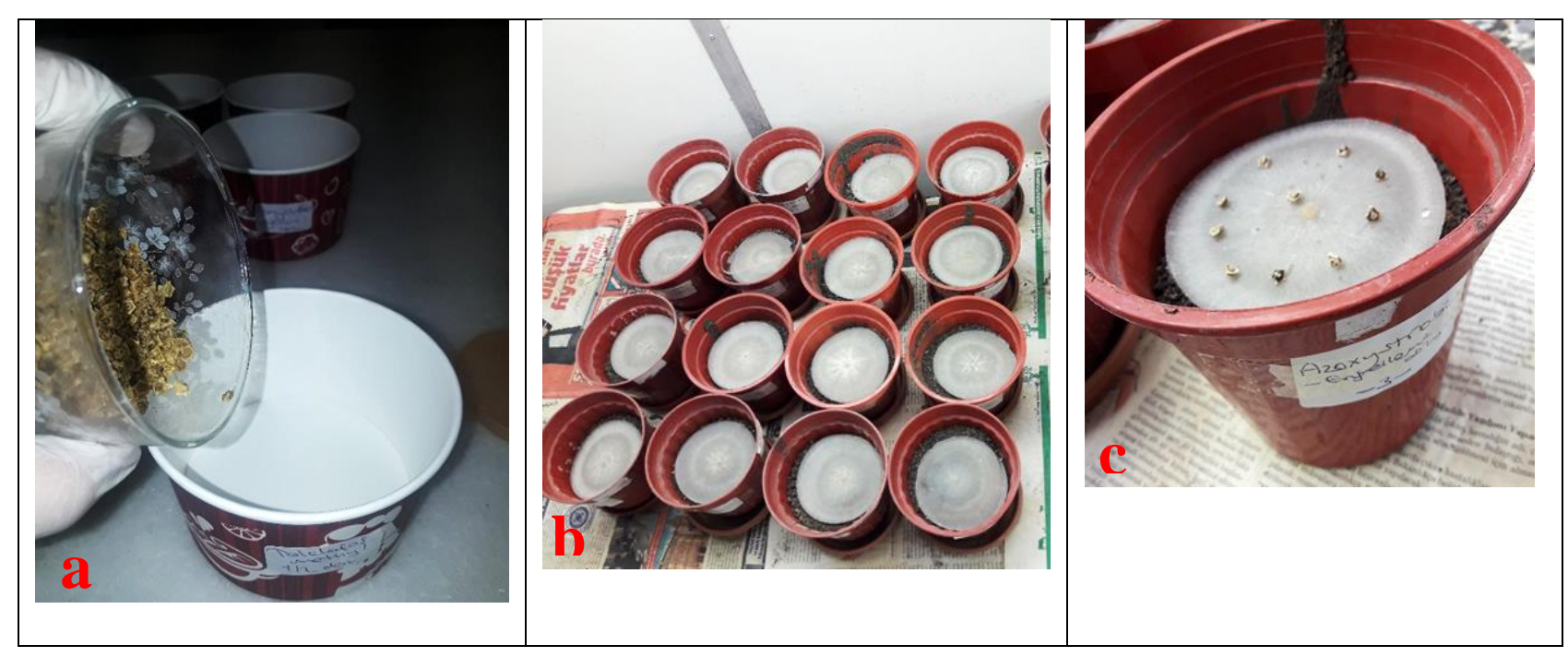

Şekil 2. Tohumların uygun fungisit dozları ile ilaçlanması ve denemenin kurulma aşamaları 


\section{Bulgular ve Tartışma}

\subsection{Fungisitlerin Rhizoctonia solani Misel Gelişimine Etkileri}

Fungisit içeren ortamlardan dökülen petrilere ekilen MN Rhizoctonia solani AG-2-2-IIIB anastomosis grubuna ait $2 \mathrm{G}$ izolatının petrilerdeki misel gelişimlerinde, $100 \mathrm{ml}$ yarı güçlü PDA ortamı için Azoxystrobin' nin engelleme dozu x10 kat dozu (1,5 ml) bulunurken, Tolclofos-methyl' in $1 / 50(1,2 \mu \mathrm{l})$, Fludioxonil' in $1 / 2000(0,01 \mu \mathrm{l})$, Flutolanil' in $1 / 2(8,75 \mu \mathrm{l})$, Pyraclostrobin + Epoxiconazole' un 1/50 (3,08 $\mu$ l), Difenoconazole + Propiconazole' un 1/2 (15 $\mu 1)$, Spiroxamine+ Prothioconazole' un $1 / 2(51 \mu \mathrm{l})$, Sedaxane + Fludioxonil + Metalaxyl-M' in 1/1000 (3.02 $\mu \mathrm{l})$ olarak tespit edilmiştir.

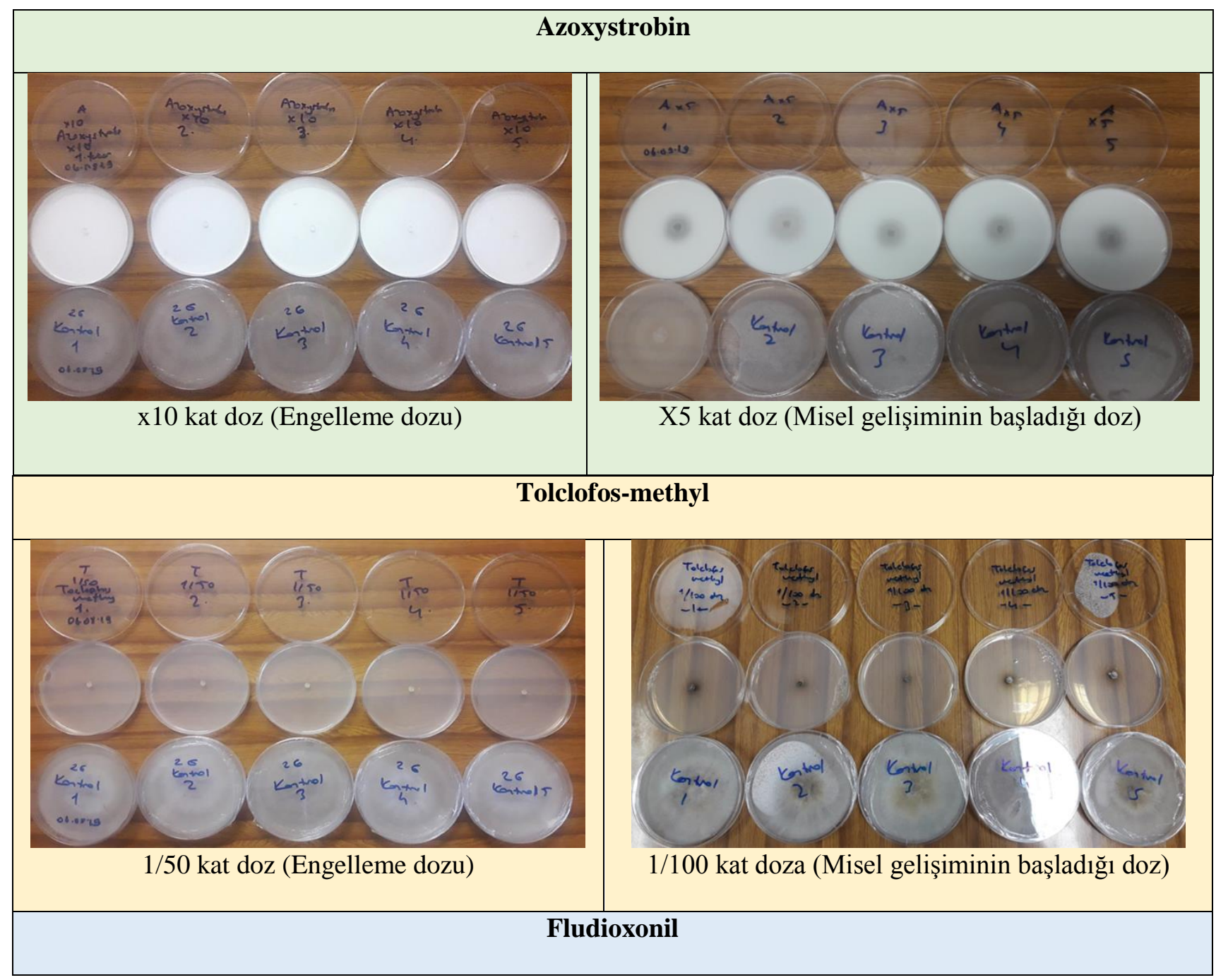


Avan, M., Katırcıoğlu, Y.Z., Uluslararası Doğu Anadolu Fen Mühendislik ve Tasarım Dergisi / International Journal of Eastern Anatolia Science Engineering and Design (IJEASED)

(2020) 2(2):169-189

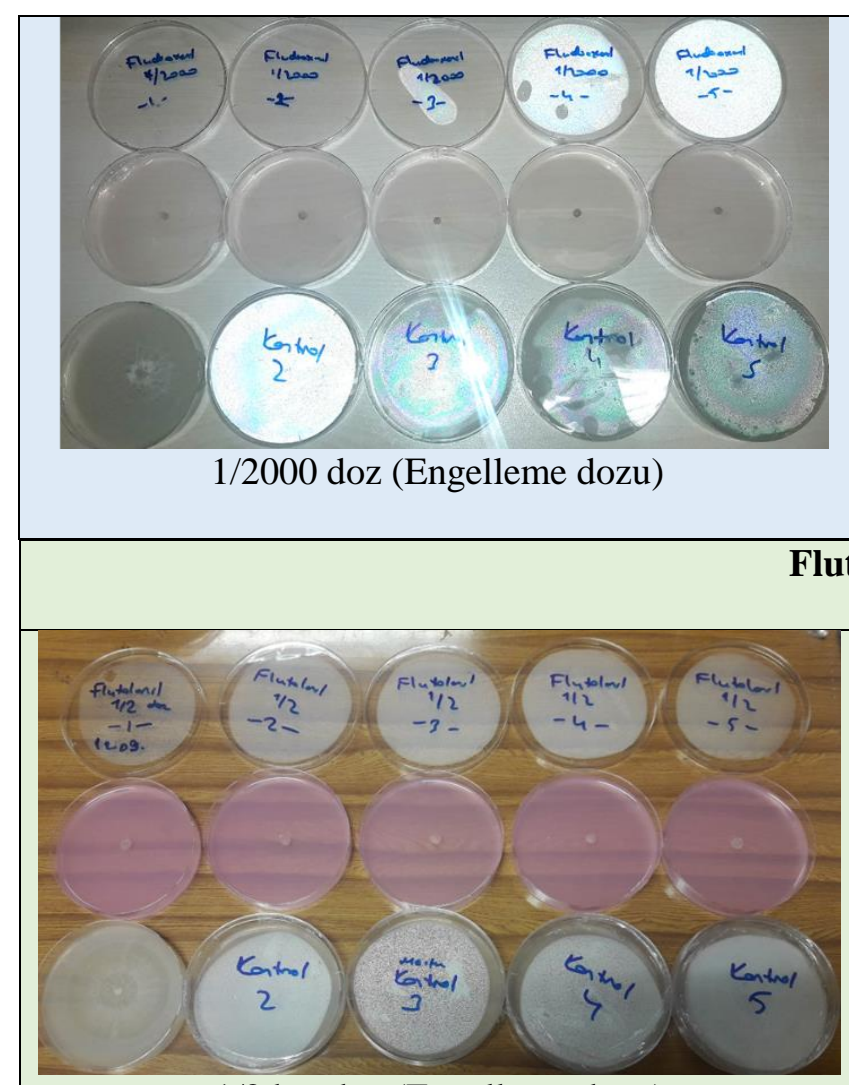

1/2 kat doz (Engelleme dozu)

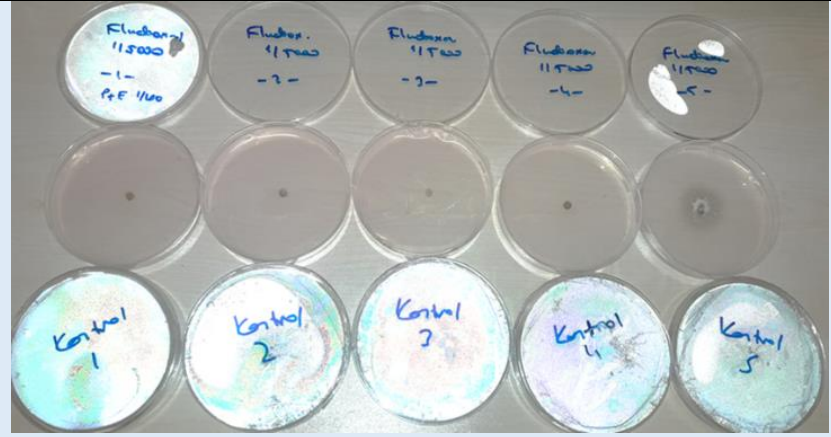

1/5000 doz (Misel gelişiminin başladığı doz)

Flutolanil

\begin{tabular}{|l|l}
\hline Pyraclostrobin + Epoxiconazole \\
\hline
\end{tabular}

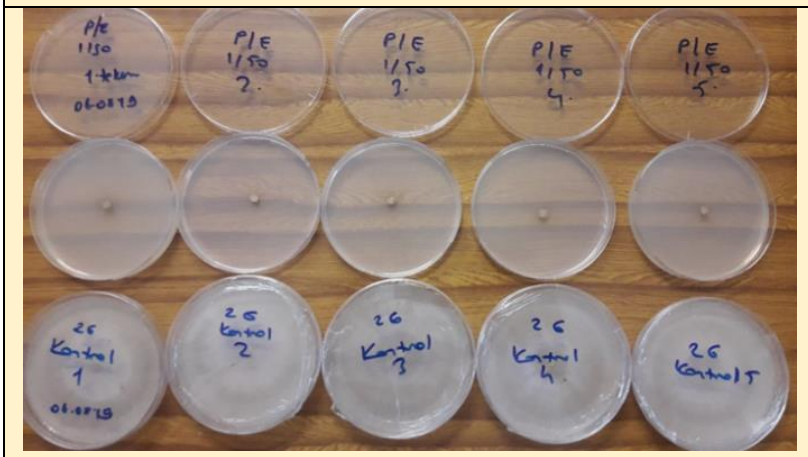

1/50 kat doz (Engelleme dozu)

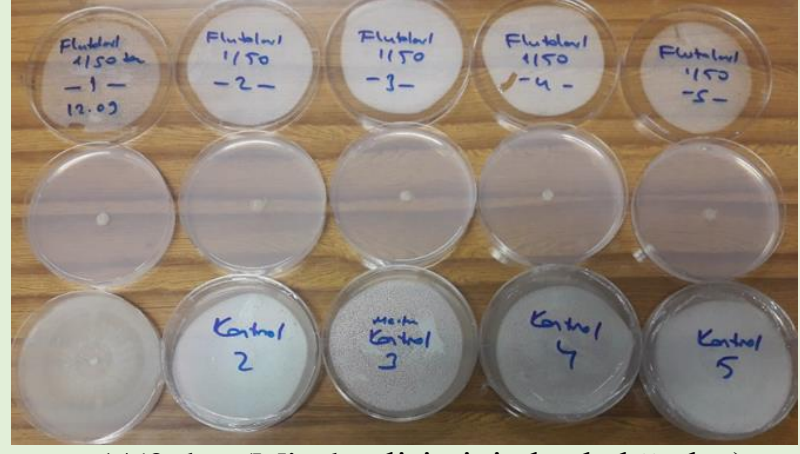

1/50 doz (Misel gelişiminin başladığı doz)

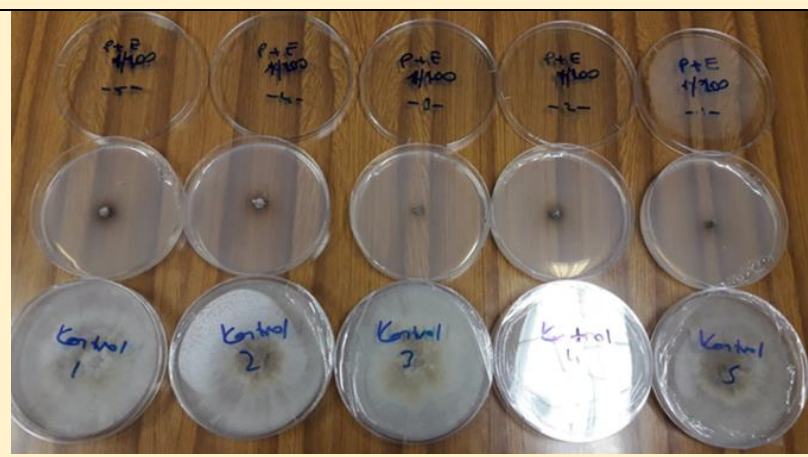

1/100 kat doz (Misel gelişiminin başladığg doz)

\section{Difenoconazole + Propiconazole}
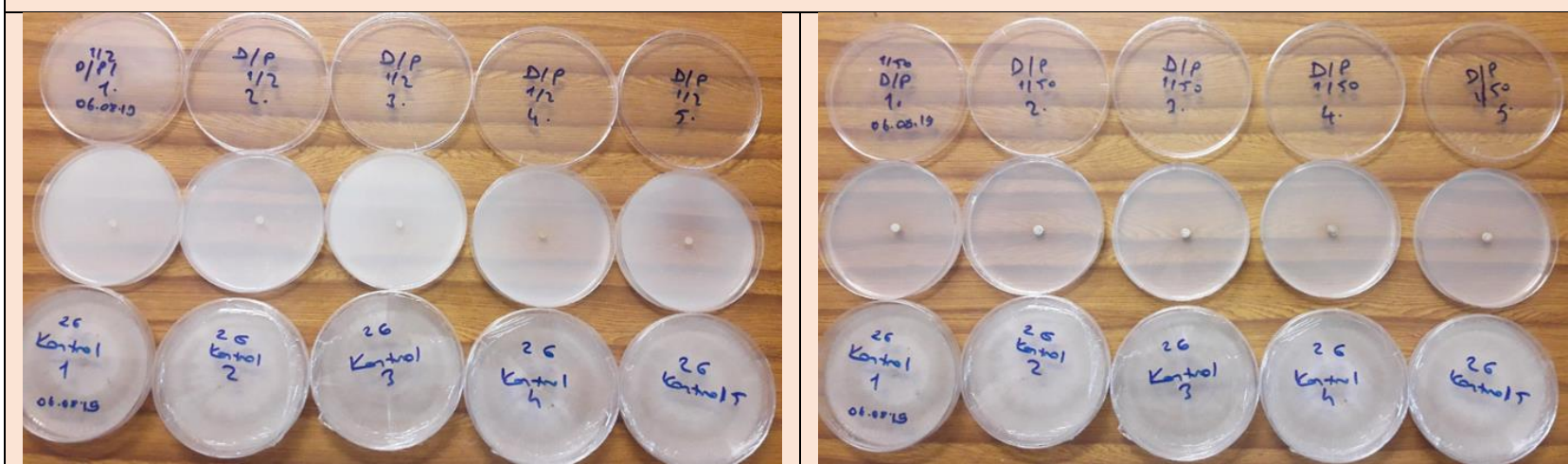


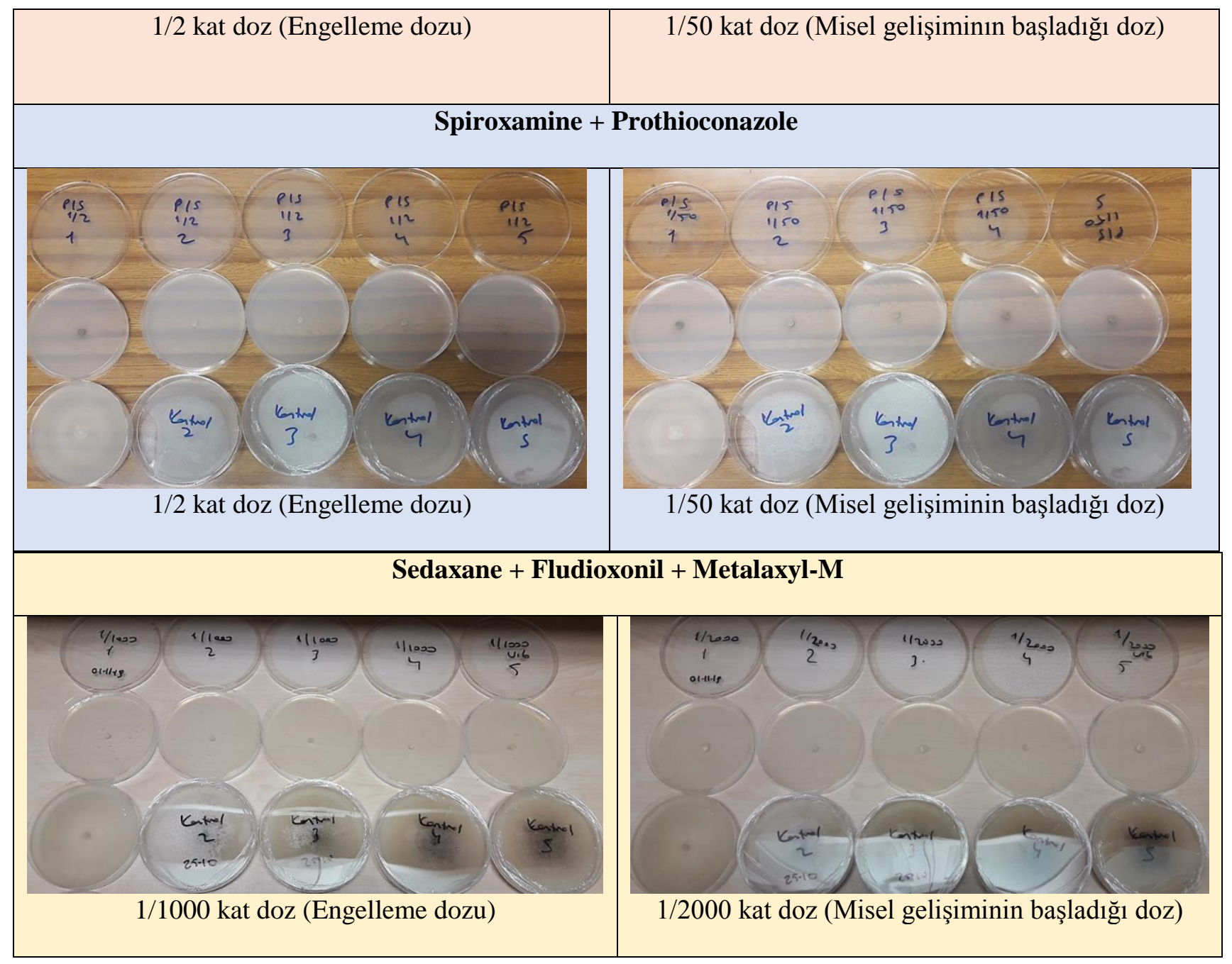

Şekil 3. Denemede kullanılan fungisitlerin engelleme dozları ve misel gelişiminin başladığ dozlarının patojene etkisi

Petri misel gelişimi denemeleri sonucunda, Azoxystrobin' in kontrol petrisinin misel koloni çap1 59.6 mm olarak hesaplanırken, 5 kat dozunda $(750 \mu \mathrm{l}) 25.8$ mm, 2 kat dozunda (300 $\mu 1) 40.6$ $\mathrm{mm}$, tam dozunda $(150 \mu \mathrm{l})$ ise $54.2 \mathrm{~mm}$ misel gelişimi tespit edilirken, $10 \mathrm{~kat}$ dozu $(1,5 \mathrm{ml})$ misel gelişiminde engelleme dozu olarak tespit edilmiştir. Deneme boyunca dozların artışına bağlı olarak oransal olarak misel gelişimi azalmaktadır. Tolclofos-methly’ in kontrol petrisinin misel koloni çap1 $59.8 \mathrm{~mm}$ olarak hesaplanırken, 1/100 kat dozunda $(0.6 \mu \mathrm{l}) 6.6 \mathrm{~mm}, 1 / 1000$ kat dozunda $(0.06 \mu \mathrm{l})$ $50.1 \mathrm{~mm}$ tespit edilirken, 1/50 kat dozu (1.2 $\mu \mathrm{l})$ misel gelişimini engelleme dozu olarak kaydedilmiştir. Flutolanil' in kontrol petrisinin misel koloni çapı 59.9 mm, 1/50 kat dozunda (0,35 4l) $2.5 \mathrm{~mm}, 1 / 100$ kat dozunda $(0,175 \mu \mathrm{l}) 15.3 \mathrm{~mm}$ tespit edilirken, yarı dozu $(8,75 \mu \mathrm{l})$ misel gelişimini engelleme dozu olarak kaydedilmiştir. Fludioxonil' in kontrol petrisinin misel koloni çapı 
$59.8 \mathrm{~mm}, 1 / 5000$ kat dozunda $(0,004 \mu \mathrm{l}) 31 \mathrm{~mm}$ tespit edilirken, 1/2000 kat dozu $(0,01 \mu \mathrm{l})$ misel gelişimini engelleme dozu olarak bulunmuştur. Pyraclostrobin+Epoxiconazole' ün kontrol petris/100 kat dozunda $(1,54 \mu \mathrm{l}) 15.4 \mathrm{~mm}, 1 / 1000$ kat dozunda $(0,154 \mu \mathrm{l})$ inin misel koloni çap1 $59.8 \mathrm{~mm}, 158 \mathrm{~mm}$ tespit edilirken, 1/50 kat dozu $(3,08 \mu \mathrm{l})$ misel gelişimini engelleme dozu olarak bulunmuştur. Difenoconazole+Propiconazole' ün kontrol petrisinin misel koloni çapı 59.7 mm, 1/50 kat dozu $(0,6 \mu \mathrm{l}) 5.8 \mathrm{~mm}, 1 / 100$ kat dozunda $(0,03 \mu \mathrm{l}) 35.2 \mathrm{~mm}$ tespit edilirken, yarı dozu $(15 \mu \mathrm{l})$ misel gelişimini engelleme dozu olarak kaydedilmiştir. Spiroxamine+Prothioconazole' ün kontrol petrisinin misel koloni çap1 $59.9 \mathrm{~mm}, 1 / 50$ kat dozu $(2,04 \mu \mathrm{l}) 3.6 \mathrm{~mm}, 1 / 100$ kat dozunda $(1,02 \mu \mathrm{l})$ $24.8 \mathrm{~mm}, 1 / 1000$ kat dozunda $(0,102 \mu \mathrm{l}) 54.4 \mathrm{~mm}$ tespit edilirken, yarı dozu $(51 \mu \mathrm{l})$ misel gelişimini engelleme dozu olarak kaydedilmiştir. Sedaxane+Fludioxonil+Metalaxyl-M' ün kontrol petrisinin misel koloni çap1 $59.8 \mathrm{~mm}, 1 / 2000$ kat dozunda $(1,51 \mu \mathrm{l}) 4.6 \mathrm{~mm}, 1 / 5000$ kat dozunda $(0,604 \mu \mathrm{l}) 45.1 \mathrm{~mm}$ tespit edilirken, 1/1000 kat dozda $(3,02 \mu 1)$ misel gelişimini engelleme dozu olarak kaydedilmiştir (Şekil 3), (Tablo 3). 
Tablo 3. İlaç misel denemesinde kullanılan fungisitlerin farklı dozlarında Rhizoctonia solani izolatlarının misel gelişimi ortalaması $(\mathrm{mm})$ ve engelleme oranları (\%)

\begin{tabular}{|c|c|c|c|c|c|c|c|c|c|c|c|c|c|}
\hline \multirow[b]{2}{*}{$\begin{array}{l}\text { Kullanılan } \\
\text { Fungisitler }\end{array}$} & & \multicolumn{12}{|c|}{ Dozlar } \\
\hline & & Kont. & $\mathbf{X 1 0 0}$ & $\mathbf{X 1 0}$ & X5 & $\mathbf{X} 2$ & $\begin{array}{c}\text { Tam } \\
\text { doz }\end{array}$ & $1 / 2$ & 1/50 & $1 / 100$ & $1 / 1000$ & $1 / 2000$ & $1 / 5000$ \\
\hline \multirow{2}{*}{ Azoxystrobin } & $\begin{array}{c}\text { Koloni } \\
\text { Çap1 }\end{array}$ & $59.6 \mathrm{a}$ & $\begin{array}{c}\text { Misel } \\
\text { gelişim } \\
\text { yok }\end{array}$ & $\begin{array}{c}\text { Engel. } \\
\text { Dozu }\end{array}$ & 25.8 & 40.6 & 54.2 & $\mathrm{x}$ & $\mathrm{x}$ & $\mathrm{x}$ & $\mathrm{x}$ & $\mathrm{x}$ & $\mathrm{x}$ \\
\hline & $\begin{array}{l}\text { Engel. } \\
\text { Oranı }\end{array}$ & 0.0 & $\begin{array}{l}\text { Misel } \\
\text { gelişim } \\
\text { yok }\end{array}$ & 100 & 56.8 & 31.9 & 9.1 & $\mathrm{x}$ & $\mathrm{x}$ & $\mathrm{x}$ & $\mathrm{x}$ & $\mathrm{x}$ & - \\
\hline \multirow{2}{*}{ Tolclofos-methly } & $\begin{array}{l}\text { Koloni } \\
\text { Çap }\end{array}$ & $59.8 \mathrm{a}$ & $\mathrm{x}$ & $\mathrm{x}$ & $\mathrm{x}$ & $\begin{array}{l}\text { Misel } \\
\text { gelişim } \\
\text { yok }\end{array}$ & $\begin{array}{l}\text { Misel } \\
\text { gelişim } \\
\text { yok }\end{array}$ & $\begin{array}{l}\text { Misel } \\
\text { gelişim } \\
\text { yok }\end{array}$ & $\begin{array}{l}\text { Engel. } \\
\text { Dozu }\end{array}$ & 6.6 & 50.1 & $\mathrm{x}$ & $\mathrm{x}$ \\
\hline & $\begin{array}{l}\text { Engel. } \\
\text { Oranı }\end{array}$ & 0.0 & $\mathrm{x}$ & $\mathrm{x}$ & $\mathrm{x}$ & $\begin{array}{l}\text { Misel } \\
\text { gelişim } \\
\text { yok }\end{array}$ & $\begin{array}{l}\text { Misel } \\
\text { gelişim } \\
\text { yok }\end{array}$ & $\begin{array}{l}\text { Misel } \\
\text { gelişim } \\
\text { yok }\end{array}$ & 100 & 89.0 & 16.3 & - & - \\
\hline \multirow{2}{*}{ Flutolanil } & $\begin{array}{l}\text { Koloni } \\
\text { Çap }\end{array}$ & 59.9 a & $\mathrm{x}$ & $\mathrm{x}$ & $\mathrm{x}$ & $\begin{array}{l}\text { Misel } \\
\text { gelişim } \\
\text { yok }\end{array}$ & $\begin{array}{l}\text { Misel } \\
\text { gelişim } \\
\text { yok }\end{array}$ & $\begin{array}{c}\text { Engel. } \\
\text { Dozu }\end{array}$ & 2.5 & 15.3 & $\mathrm{x}$ & $\mathrm{x}$ & $\mathrm{x}$ \\
\hline & $\begin{array}{l}\text { Engel. } \\
\text { Oranı }\end{array}$ & 0.0 & $\mathrm{x}$ & $\mathrm{x}$ & $\mathrm{x}$ & $\begin{array}{l}\text { Misel } \\
\text { gelişim } \\
\text { yok }\end{array}$ & $\begin{array}{l}\text { Misel } \\
\text { gelişim } \\
\text { yok }\end{array}$ & 100 & 95.9 & 74.5 & $\mathrm{x}$ & $\mathrm{x}$ & - \\
\hline \multirow{2}{*}{ Fludioxonil } & $\begin{array}{l}\text { Koloni } \\
\text { Çap }\end{array}$ & $59.8 \mathrm{a}$ & $\mathrm{x}$ & $\mathrm{x}$ & $\mathrm{x}$ & $\begin{array}{l}\text { Misel } \\
\text { gelişim } \\
\text { yok }\end{array}$ & $\begin{array}{l}\text { Misel } \\
\text { gelişim } \\
\text { yok }\end{array}$ & $\begin{array}{l}\text { Misel } \\
\text { gelişim } \\
\text { yok }\end{array}$ & $\begin{array}{l}\text { Misel } \\
\text { gelişim } \\
\text { yok }\end{array}$ & $\begin{array}{l}\text { Misel } \\
\text { gelişim } \\
\text { yok }\end{array}$ & $\begin{array}{l}\text { Misel } \\
\text { gelişim } \\
\text { yok }\end{array}$ & $\begin{array}{c}\text { Engel. } \\
\text { Dozu }\end{array}$ & 31 \\
\hline & $\begin{array}{l}\text { Engel. } \\
\text { Oranı }\end{array}$ & 0.0 & $\mathrm{x}$ & $\mathrm{x}$ & $\mathrm{x}$ & $\begin{array}{l}\text { Misel } \\
\text { gelişim } \\
\text { yok }\end{array}$ & $\begin{array}{l}\text { Misel } \\
\text { gelişim } \\
\text { yok }\end{array}$ & $\begin{array}{l}\text { Misel } \\
\text { gelişim } \\
\text { yok }\end{array}$ & $\begin{array}{l}\text { Misel } \\
\text { gelişim } \\
\text { yok }\end{array}$ & $\begin{array}{l}\text { Misel } \\
\text { gelişim } \\
\text { yok }\end{array}$ & $\begin{array}{l}\text { Misel } \\
\text { gelişim } \\
\text { yok }\end{array}$ & 100 & 48.2 \\
\hline \multirow{2}{*}{$\begin{array}{c}\text { Pyraclostrobin } \\
+ \\
\text { Epoxiconazole }\end{array}$} & $\begin{array}{l}\text { Koloni } \\
\text { Çap }\end{array}$ & $59.8 \mathrm{a}$ & $\mathrm{x}$ & $\mathrm{x}$ & $\mathrm{x}$ & $\begin{array}{l}\text { Misel } \\
\text { gelişim } \\
\text { yok }\end{array}$ & $\begin{array}{l}\text { Misel } \\
\text { gelişim } \\
\text { yok }\end{array}$ & $\begin{array}{l}\text { Misel } \\
\text { gelişim } \\
\text { yok }\end{array}$ & $\begin{array}{l}\text { Engel. } \\
\text { Dozu }\end{array}$ & 15.4 & 58 & $\mathrm{x}$ & $\mathrm{x}$ \\
\hline & $\begin{array}{l}\text { Engel. } \\
\text { Oranı }\end{array}$ & 0.0 & $\mathrm{x}$ & $\mathrm{x}$ & $\mathrm{x}$ & $\begin{array}{l}\text { Misel } \\
\text { gelişim } \\
\text { yok }\end{array}$ & $\begin{array}{l}\text { Misel } \\
\text { gelişim } \\
\text { yok }\end{array}$ & $\begin{array}{l}\text { Misel } \\
\text { gelişim } \\
\text { yok }\end{array}$ & 100 & 74.3 & 3.1 & $\mathrm{x}$ & \\
\hline \multirow{2}{*}{$\begin{array}{l}\text { Difenoconazole+ } \\
\text { Propiconazole }\end{array}$} & $\begin{array}{l}\text { Koloni } \\
\text { Çap }\end{array}$ & $59.7 \mathrm{a}$ & $\mathrm{x}$ & $\mathrm{x}$ & $\mathrm{x}$ & $\begin{array}{l}\text { Misel } \\
\text { gelişim } \\
\text { yok }\end{array}$ & $\begin{array}{l}\text { Misel } \\
\text { gelişim } \\
\text { yok }\end{array}$ & $\begin{array}{l}\text { Engel. } \\
\text { Dozu }\end{array}$ & 5.8 & 35.2 & $\mathrm{x}$ & $\mathrm{x}$ & $\mathrm{x}$ \\
\hline & $\begin{array}{l}\text { Engel. } \\
\text { Oranı }\end{array}$ & 0.0 & $\mathrm{x}$ & $\mathrm{x}$ & $\mathrm{x}$ & $\begin{array}{l}\text { Misel } \\
\text { gelişim } \\
\text { yok }\end{array}$ & $\begin{array}{l}\text { Misel } \\
\text { gelişim } \\
\text { yok }\end{array}$ & 100 & 90.3 & 41.1 & $\mathrm{x}$ & $\mathrm{x}$ & - \\
\hline \multirow{2}{*}{$\begin{array}{c}\text { Spiroxamine } \\
+ \\
\text { Prothioconazole }\end{array}$} & $\begin{array}{l}\text { Koloni } \\
\text { Çap }\end{array}$ & $59.9 \mathrm{a}$ & $\mathrm{x}$ & $\mathrm{x}$ & $\mathrm{x}$ & $\begin{array}{l}\text { Misel } \\
\text { gelişim } \\
\text { yok }\end{array}$ & $\begin{array}{l}\text { Misel } \\
\text { gelişim } \\
\text { yok }\end{array}$ & $\begin{array}{l}\text { Engel. } \\
\text { Dozu }\end{array}$ & 3.6 & 24.8 & 54.4 & $\mathrm{x}$ & $\mathrm{X}$ \\
\hline & $\begin{array}{l}\text { Engel. } \\
\text { Oranı }\end{array}$ & 0.0 & $\mathrm{x}$ & $\mathrm{x}$ & $\mathrm{x}$ & $\begin{array}{l}\text { Misel } \\
\text { gelişim } \\
\text { yok }\end{array}$ & $\begin{array}{l}\text { Misel } \\
\text { gelişim } \\
\text { yok }\end{array}$ & 100 & 94.0 & 58.6 & 9.2 & $\mathrm{x}$ & - \\
\hline \multirow{2}{*}{$\begin{array}{c}\text { Sedaxane+ } \\
\text { Fludioxonil+ } \\
\text { Metalaxyl-M }\end{array}$} & $\begin{array}{l}\text { Koloni } \\
\text { Çap }\end{array}$ & $59.8 \mathrm{a}$ & $\mathrm{x}$ & $\mathrm{x}$ & $\mathrm{x}$ & $\begin{array}{l}\text { Misel } \\
\text { gelişim } \\
\text { yok }\end{array}$ & $\begin{array}{l}\text { Misel } \\
\text { gelişim } \\
\text { yok }\end{array}$ & $\begin{array}{l}\text { Misel } \\
\text { gelişim } \\
\text { yok }\end{array}$ & $\begin{array}{l}\text { Misel } \\
\text { gelişim } \\
\text { yok }\end{array}$ & $\begin{array}{l}\text { Misel } \\
\text { gelişim } \\
\text { yok }\end{array}$ & $\begin{array}{l}\text { Engel. } \\
\text { Dozu }\end{array}$ & 4.6 & 45.1 \\
\hline & $\begin{array}{l}\text { Engel. } \\
\text { Oranı }\end{array}$ & 0.0 & $\mathrm{x}$ & $\mathrm{x}$ & $\mathrm{x}$ & $\begin{array}{l}\text { Misel } \\
\text { gelişim } \\
\text { yok }\end{array}$ & $\begin{array}{l}\text { Misel } \\
\text { gelişim } \\
\text { yok }\end{array}$ & $\begin{array}{l}\text { Misel } \\
\text { gelişim } \\
\text { yok }\end{array}$ & $\begin{array}{l}\text { Misel } \\
\text { gelişim } \\
\text { yok }\end{array}$ & $\begin{array}{l}\text { Misel } \\
\text { gelişim } \\
\text { yok }\end{array}$ & 100 & 92.3 & 24.6 \\
\hline
\end{tabular}

Not: : Koloni Çapı: Koloni Çaplarının Ortalaması (5 tekerrür için), Engel. Oranı: Engelleme Oranı, Engel. Dozu: Engelleme dozu, X: Çalışma yapılmayan dozlar

Çalışmada koloni çapı özelliği açısından farklı ilaçların dozları ayrı ayrı değerlendirilerek MINITAB paket programı kullanılarak Varyans Analizine tabi tutulmuştur. Dozlar arasındaki farklılıkların belirlenmesi için Tukey çoklu karşılaştırma testi kullanılmıştır. Fungisitlerin farklı dozlarının \% etkileri de Abbott formülü ile hesaplanmıştır (Karman, 1971). 
Avan, M., Katırcıoğlu, Y.Z., Uluslararası Doğu Anadolu Fen Mühendislik ve Tasarım Dergisi / International Journal of Eastern Anatolia Science Engineering and Design (IJEASED)

(2020) 2(2):169-189

\section{2. İklim Odasında Fungisitlerin Rhizoctonia solani’ ye Karşı Etkileri}

Petri misel denemesi sonucu elde edilen fungisitlerin engelleme dozları ile birlikte önerilen tam dozları, yarı dozları ve iki kat dozları denemede kullanılmıştır (Tablo 4).

Tablo 4. İlaç denemesinde kullanılan ilaçlar ve dozları ( $\mu 1 / 7 \mathrm{~g}$ tohum)

\begin{tabular}{|c|c|c|c|c|}
\hline İlaçlar & $\begin{array}{c}\text { x2 kat } \\
\text { doz }\end{array}$ & Tam doz & $1 / 2$ kat doz & Engelleme dozu \\
\hline Azoxystrobin & $21 \mu 1$ & $10,5 \mu 1$ & $5,25 \mu 1$ & $105 \mu 1$ \\
\hline Tolclofos-methyl & $8,4 \mu \mathrm{l}$ & $4,2 \mu 1$ & $2,1 \mu 1$ & $0,084 \mu 1$ \\
\hline Fludioxonil & $2,8 \mu 1$ & $1,4 \mu 1$ & $0,7 \mu 1$ & $0,007 \mu 1$ \\
\hline Flutolanil & $2,45 \mu 1$ & $1,225 \mu 1$ & $0,612 \mu 1$ & $0,612 \mu 1$ \\
\hline Spiroxamine + Prothioconazole & $14,28 \mu 1$ & $7.14 \mu 1$ & $3,57 \mu 1$ & $3,57 \mu l$ \\
\hline Pyraclostrobin + Epoxiconazole & $21,56 \mu 1$ & $10,78 \mu l$ & $5,39 \mu 1$ & $0,215 \mu 1$ \\
\hline Difenoconazole + Propiconazole & $4,2 \mu 1$ & $2,1 \mu 1$ & $1,05 \mu 1$ & $1,05 \mu 1$ \\
\hline Sedaxane + Fludioxonil + Metalaxyl-M & $422 \mu 1$ & $211 \mu 1$ & $105 \mu 1$ & $0,211 \mu 1$ \\
\hline
\end{tabular}

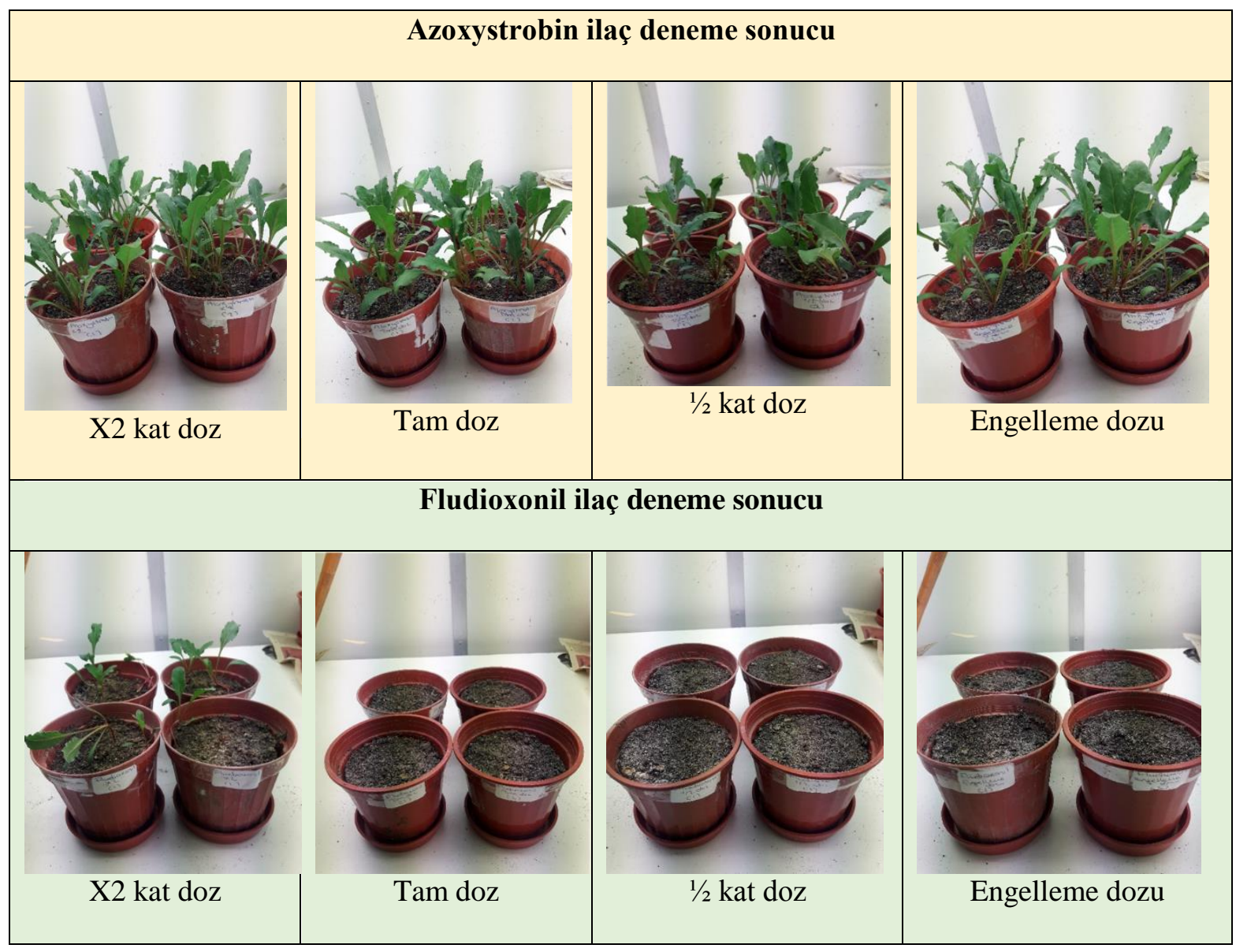




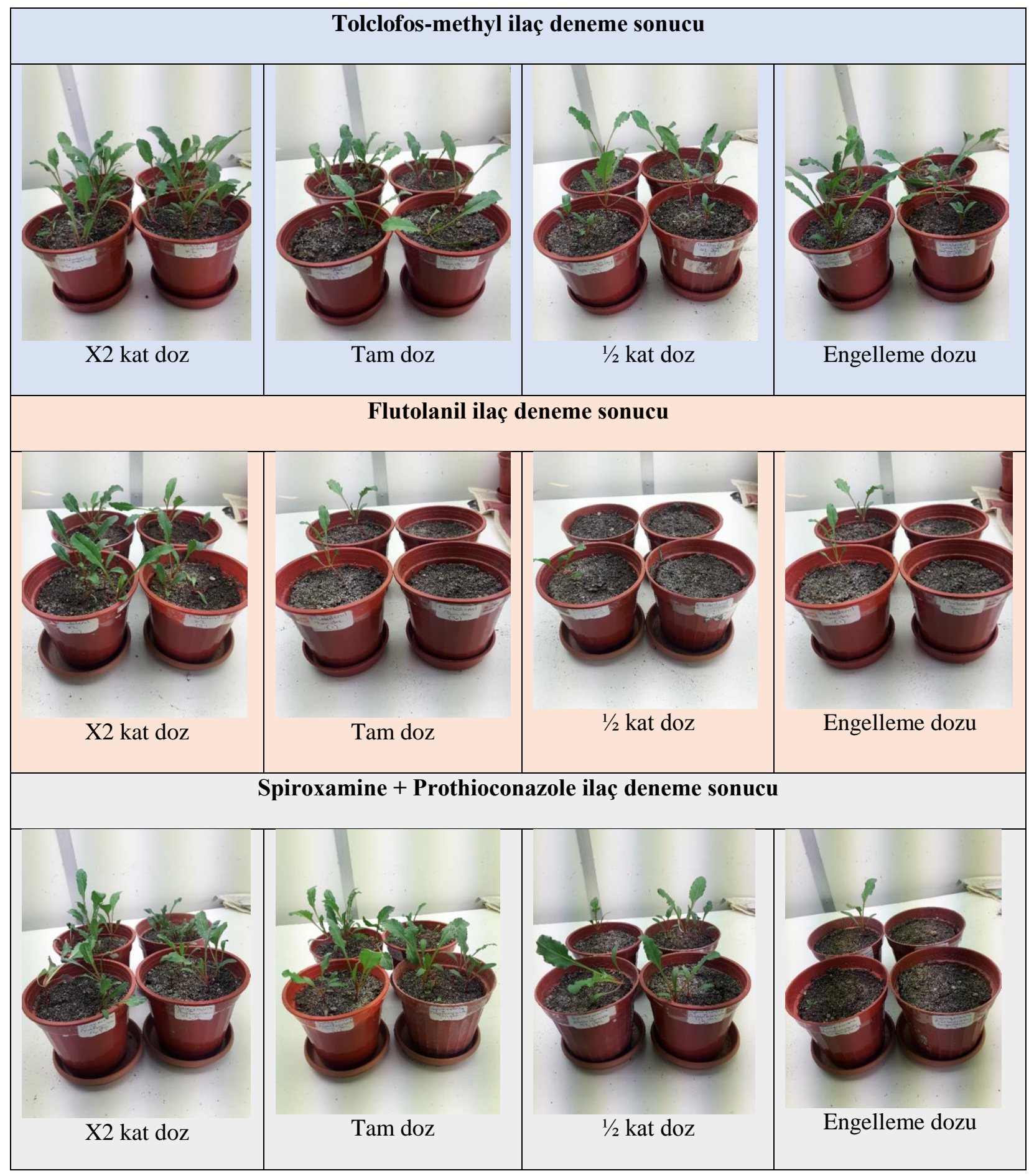




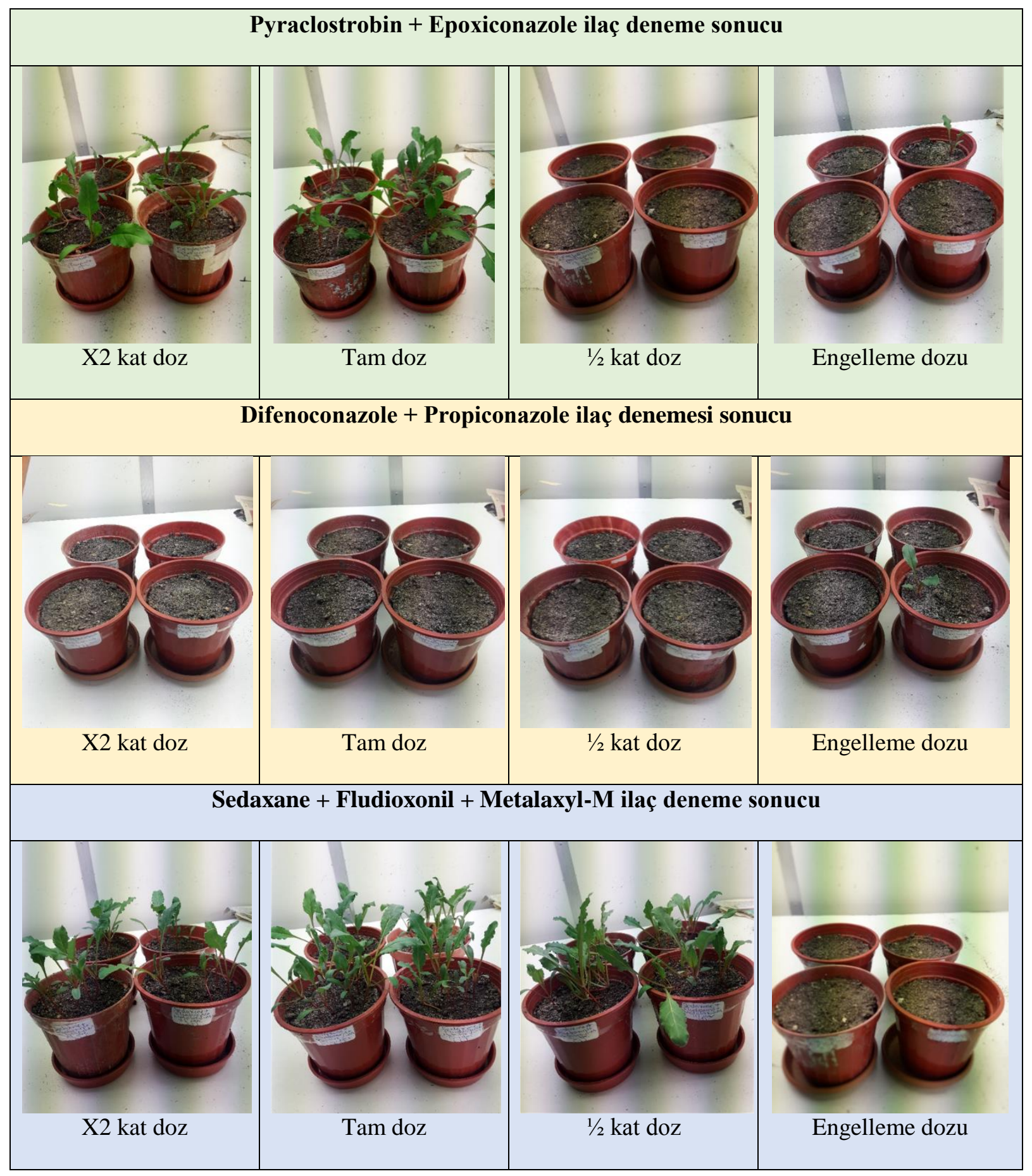

Şekil 4. Fungisitlerin 4 farklı dozunun Rhizoctonia solani patojenine karşı saksı denemesindeki etkileri 


\section{3. Kontrol Grubu Saksilar}

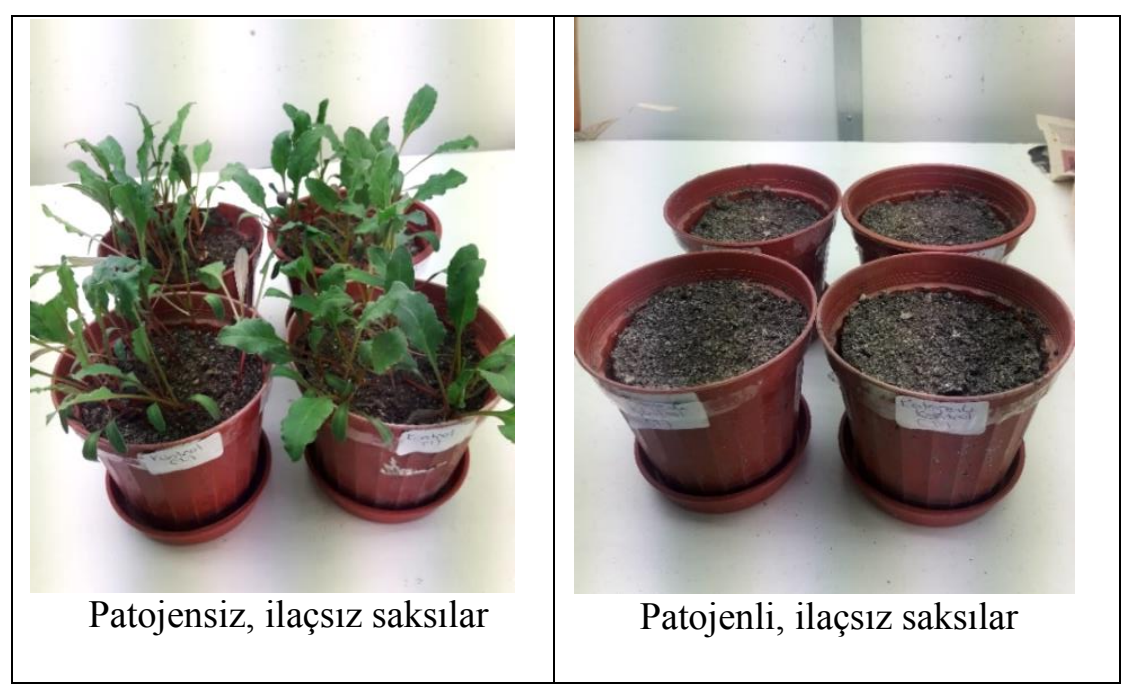

Şekil 5. Denemede kullanılan patojenli ve patojensiz kontrol grubu saksılar

Çalışmada fungisitlerin 4 ayrı dozlarına göre görsel sonuçları Şekil 4' de detaylıca verilmiştir. Dozların artışlarına bağlı olarak saksı denemelerindeki sonuçlar genellikle oransal olarak artmıştır. Fakat Sedaxane + Fludioxonil + Metalaxyl-M etken maddeli fungisitte çift kat dozdaki etki tam doza göre daha düşük görülmüştür. Kontrol saksı grupları ise hem patojenli hem patojensiz olarak iki ayrı şekilde kurulmuştur, patojensiz olanlarda tüm tohumlarda çıkışlar ve sağlıklı fideler elde edilmişken, patojenli kontrollerde tüm tohumlar çıkış yapamadan çökertene maruz kalmışlardır (Şekil 5).

Deneme kurulduktan 1 hafta sonra azoxystrobin ve tolclofos-methyl ile ilaçlanan tohumların 1 haftalık fidelerinde çökertenler meydana gelmeye başlamıştır (Şekil 6). Fludioxonil, Flutolanil, Pyraclostrobin + Epoxioconazole ve Difenoconazole + Propiconazole beklenen çıkışlar görülmemiştir.

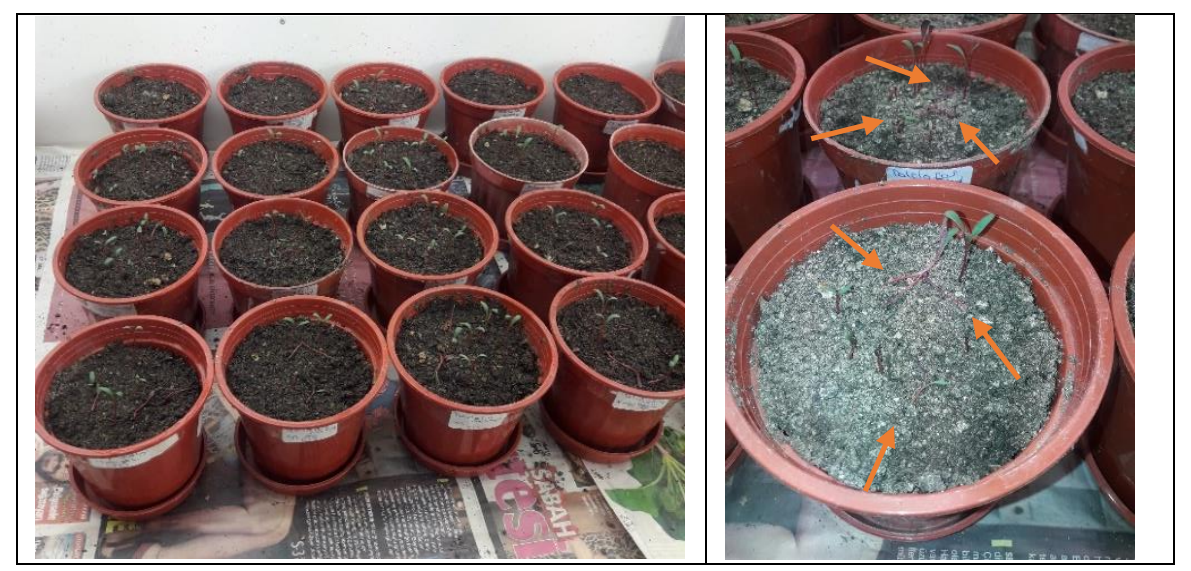

Şekil 6. Tolclofos-methyl ile ilaçlanan tohumların 1 haftalık fidelerinde meydana gelen çökertenler 
Çalışmada gözlenen endeks değerleri, derecelendirmeye bağlı olarak belirlenmiş değerler olmasından hem de parametrik bir yöntem olan varyans analizinin ön şartlarını yerine getirmemiş olmasından dolayı veriler parametrik olmayan test yöntemi olan Kruskal-Wallis yöntemi uygulanarak analiz edilmiştir. Uygulanan analiz sonucuna bağlı olarak gerekli olduğu zaman hangi gruplar arasındaki farkların istatistik olarak önemli olduğu çoklu karşılaştırma testi uygulanarak kontrol edilmiştir. Analizler MINITAB istatistik paket programı kullanılarak yapılmıştır (Tablo 5).

Tablo 5. Fungisitlerin 4 farklı dozları ile patojen arasındaki Kruskal-Wallis test yöntemi ile çoklu ve tüm ikili karşılastırmalar sonuçları

\begin{tabular}{|c|c|c|}
\hline \multirow[b]{2}{*}{ FUNGISITLLER } & \multicolumn{2}{|c|}{ Tam doz, yarı doz, $x 2$ kat doz ve engelleme dozu için } \\
\hline & $\begin{array}{c}\text { Çoklu } \\
\text { Karşılaştırma }\end{array}$ & Tüm ikili karşılaştırmalar \\
\hline Azoxystrobin & $\mathrm{P}=0,096>0.05$ & $\begin{array}{l}\text { Dozlar arasında gözlenen farkların istatistik } \\
\text { olarak önemli değildir. }\end{array}$ \\
\hline Tolclofos-methyl & $\mathrm{P}=0,019<0.05$ & $\begin{array}{l}\text { x2 kat doz - } 1 / 2 \text { doz, } \\
\text { x2 kat doz- ED arasındaki fark önemlidir. }\end{array}$ \\
\hline Flutolanil & $\mathrm{P}=0,020<0.05$ & $\begin{array}{l}\text { x2 kat doz - tam doz, } \\
\text { x2 kat doz - } 1 / 2 \text { doz, } \\
\text { x2 kat dozla - ED arasındaki fark önemlidir. }\end{array}$ \\
\hline Fludioxonil & $\mathrm{P}=0,020<0.05$ & $\begin{array}{l}\text { x2 kat doz - tam doz, } \\
\text { x2 kat doz - } 1 / 2 \text { doz, } \\
\text { x2 kat dozla - ED arasindaki fark önemlidir. }\end{array}$ \\
\hline Pyraclostrobin+Epoxiconazole & $\mathrm{P}=0,003<0.05$ & $\begin{array}{l}\text { Tam doz - yarı doz } \\
\text { tam doz - ED arasındaki fark önemlidir. }\end{array}$ \\
\hline Difenoconazole+Propiconazole & $\mathrm{P}=0,392>0.05$ & $\begin{array}{l}\text { Dozlar arasında gözlenen farkların istatistik } \\
\text { olarak önemli değildir. }\end{array}$ \\
\hline Prothioconazole+Spiroxamine & $\mathrm{P}=0,007<0.05$ & $\begin{array}{l}\text { ED - tam doz, } \\
\text { ED - x2 kat doz arasındaki fark önemlidir. }\end{array}$ \\
\hline $\begin{array}{l}\text { Sedaxane+Fludioxonil } \\
+ \text { Metalaxyl-M }\end{array}$ & $\mathrm{P}=0,005<0.05$ & Tam doz - ED arasındaki fark önemlidir. \\
\hline
\end{tabular}

Azoxystrobin' de kullanılan dozlar arasında istatistiksel olarak önemli bir fark gözlemlenmemiştir ( $\mathrm{P}>0.05)$. Tüm dozların patojene etkileri birbirine benzer bulunsa da 2 kat dozun \%95 gibi yüksek bir yüzde etki ile diğer dozlardan bir miktar daha etkili olduğu gözlenmiştir. Diğer tüm fungisitlerde dozlar arasında istatistiksel olarak fark önemli bulunmuştur $(\mathrm{P}<0.05)$, Tolclofos-methyl' de çift kat doz hem engelleme dozundan hem de yarı dozdan etkili bulunurken, çift kat dozla tam doz arasındaki fark istatistiksel olarak önemli bulunmamıştır ve çift kat dozda \% 62.5, tam dozda ise \% 42.5'luk bir yüzde etkileri olduğu görülmektedir. Flutolanil ve Fludioxonil' de çift kat dozlarının diğer dozlara oranla bu fungisitlerin çok düşükte olsa \%32.5 ve \%25 gibi düşük oranlarda etkisi olduğu söylenebilmektedir. Pyraclostrobin+Epoxiconazole' de tam dozda 
\%50 oranında, çift kat dozda ise $\% 32.5$ gibi düşük oranlarda patojene karşı yüzde etkileri mevcuttur. Difenoconazole+Propiconazole'de tüm dozlar patojene karşı etkisiz bulunmuştur. Prothioconazole+Spiroxamine' de en düşük yüzde etki \%7.5 ile engelleme dozunda olduğu için, bu dozun tam doz ve çift kat dozdan istatistiksel olarak ta farklı bulunmuştur. En iyi yüzde etki \%65 ile çift kat dozda tespit edilmiştir. Sedaxane+Fludioxonil+Metalaxyl-M’ de tam doz \%87.5 gibi yüksek bir yüzde etki ile engelleme dozunun \% 0 lık etkisi ile istatistiksel olarak ayrılmıştır (Tablo 5, Tablo $6)$.

Tablo 6. Saksı denemesinde kullanılan fungisitlerin farklı dozlarının patojene yüzde etkileri

\begin{tabular}{lcccc}
\hline \multirow{2}{*}{ Fungisitler } & \multicolumn{4}{c}{ Dozlar } \\
\cline { 2 - 5 } & \multicolumn{4}{c}{ Yüzde Etkileri } \\
\cline { 2 - 5 } & $\mathbf{T a m}$ & $\mathbf{1 / 2}$ & $\mathbf{X 2}$ & ED \\
\hline Azoxystrobin & 72.5 & 67.5 & 95 & 77.5 \\
\hline Tolclofos-methyl & 42.5 & 25 & 62.5 & 32.5 \\
\hline Flutolanil & 5 & 2.5 & 32.5 & 2.5 \\
\hline Fludioxonil & 0 & 0 & 25 & 0 \\
\hline Pyraclostrobin+ Epoxiconazole & 50 & 0 & 32.5 & 2.5 \\
\hline Difenoconazole+Propiconazole & 0 & 0 & 0 & 2.5 \\
\hline Spiroxamine+Prothioconazole & 45 & 25 & 65 & 7.5 \\
\hline Sedaxane+Fludioxonil & 87.5 & 57.5 & 45 & 0 \\
+Metalaxyl-M & & & & \\
\hline
\end{tabular}

Tablo 7. Petri misel ve saksı denemelerinde kullanılan ilaçlar ve etkili bulunan dozları

\begin{tabular}{lll}
\hline \multicolumn{1}{c}{ Fungisitler } & \multicolumn{1}{c}{$\begin{array}{c}\text { Petri Misel } \\
\text { Gelişiminde } \\
\text { Engelleme Dozu }\end{array}$} & $\begin{array}{c}\text { İklim Odası Saksı denemesinde } \\
\text { En Etkili Bulunan Doz ve \% Etki } \\
\text { Değeri }\end{array}$ \\
\hline Azoxystrobin & X10 doz & X2 (\%95) \\
\hline Tolclofos-methyl & $1 / 50$ & X2 $(\% 62.5)$ \\
\hline Flutolanil & $1 / 2$ & X2 (\%32.5) \\
\hline Fludioxonil & $1 / 2000$ & X2 (\%25) \\
\hline Pyraclostrobin+ Epoxiconazole & $1 / 50$ & Tam doz (\%50) \\
\hline Difenoconazole+Propiconazole & $1 / 2$ & Etkili sonuç yok \\
\hline Spiroxamine+Prothioconazole & $1 / 2$ & X2 $(\% 65)$ \\
\hline Sedaxane+Fludioxonil+Metalaxyl-M & $1 / 1000$ & Tam doz $(\% 87.5)$ \\
\hline
\end{tabular}

Petri denemesi ile saksı denemelerinde etkili bulunan dozlar arasında uyumluluk gözlemlenmemiştir. Azoxystrobinde petri denemesinde 10 kat doz (1,5 ml) etkili bulunurken, kullanılan tüm dozların genel olarak şeker pancarı fidelerinde çökerteni engellemiş olmasına rağmen en büyük etki çift kat dozda $(\% 95)$ tespit edilmiştir. En düşük etki ise $1 / 2$ dozda elde edilmiştir. Petri denemesinde tespit edilen bu yüksek dozun saksı denemesinde tohumlar üzerinde kısmen toksik etki yaratmış olabileceğinden dolayı 10 kat dozu olan engelleme dozunda en yüksek 
oranda etki bulunmamıştır. Buna karşın çift kat dozdan sonra yine de en etkin doz olarak kaydedilmiştir.

Tolclofos-methyl'de 1/50 kat $(1,2 \mu \mathrm{l})$, Flutolanil 1/2 kat $(8,75 \mu 1)$, Fludioxonil 1/2000 kat $(0.01 \mu \mathrm{l})$ ve Spiroxamine+Prothioconazole' da 1/2 kat $(51 \mu \mathrm{l})$ dozu daha düşük dozlar olacak şekilde petri denemesinde misel gelişimini engellerken, saksı denemesinde x2 kat dozları daha etkin bulunmuştur. Pyraclostrobin+Epoxiconazole' de $1 / 50$ kat $(3,08 \mu 1)$ ve Sedaxane+Fludioxonil+Metalaxyl-M' de 1/1000 kat $(3,02 \mu 1)$ doz ile yine çok düşük dozlarla petride etki sağlamışken, saksıda tam dozlarının daha uygun olduğu gözlemlenmiştir (Tablo 7).

Saksı ilaç denemeleri sonunda Azoxystrobin'in çift kat dozu ile henüz ülkemizde ruhsatı olmayan karışım olarak kullandığımız Sedaxane+Fludioxonil+Metalaxyl-M etken maddeli fungisitin tam dozunun en etkili ilaçlar olduğu kanısına varılmıştır. Spiroxamine+Prothioconazole'un çift kat dozu, Tolclofos-methyl' ün çift kat dozu ve Pyraclostrobin+ Epoxiconazole' ün de tam dozu \%50-65 oranında orta etkili fungisitler arasında oldukları çalışmamızda tespit edilmiştir.

Bolton ve ark. (2010) şeker pancarı fidelerinde tespit edilmiş olan AG-2-2-IIIB ve AG-2-2-IV izolatlarına karşı azoxystrobin ve flutolanil' in yüksek oranda etkili olduğunu bildirmişlerdir. Bizim çalışmamızda da azoxystrobinin çift kat dozu etkili bulunmasının patojene karşı direnç gelişimi olduğunu düşündürmektedir. Arabiat ve Khan (2016) şeker pancarında Rhizoctonia' nın AG-2-2 izolatlarında, Djébali ve ark. (2014) Tunus' ta patateste AG-3 izolatları üzerinde kullanılan dozlardaki artıştan dolayı patojenin Azoxystrobin’ e karşı oluşan direnci vurgulamışlardır.

Kataria ve ark. (1989) börülcelerde yapmış olduğu çalışmasında $R$. solani ile enfekteli fidelerdeki çürümelere karşı, tolclofos-metil' i en etkili fungisit olarak bulurken yine aynı araştırıcının 1991 yılında yapmış olduğu çalışmasında Tolclofos-metil' in AG-2-1 ve AG-4 izolatlarıyla istila edilen saksılarda fidelerdeki çökerteni \% 75-100 oranında engellediğini tespit etmişlerdir. Long ve Xiaolin (2001) labaratuvarda yapmış olduğu petri testlerinde tolclofos-metil' in çeltikten elde edilen $R$. solani gelişimi için iyi bir kontrol sağladığını bildirmişlerdir. Bu çalışmalar \% 62.5' luk bir etki ile orta derecede tolclofos-methyl etkisi ile kısmen uyuşmaktadır.

Zhao ve ark. (2019) Rhizoctonia izolatlarının, in vitro çalışmalarda flutolanil' e karşı son derece hassas olduğunu, geliştirilmiş flutolanil ortamında (flutolanil-amended media) 2 adet dirençli izolata rastlanmıştır. Bu dirençli izolatların şeker pancarı fideleri üzerinde belirli sıcaklıklarda misel gelişme oranını düşürdüğünü ve patojenin virülensliğini düşürdüğünü ifade etmişlerdir. Cotterill ve ark. (1989) propiconazole ve flutolanil' in petri çalışmasında agar üzerinde $R$. solani gelişmesini 
engellediğini fakat saksı denemelerinde enfekte olan bitki sayısını azaltmadığını bildirmişlerdir. Bizim çalışmamızda da benzer şekillerde petri çalışmasında patojen gelişimini yarı dozda engellediği halde, saksı denemesinde x2 kat dozda kısmen (\% 40-50) çökerteni engellediği görülmüş̧ür. Hamada ve ark. (2011) buğdaydan elde edilen $R$. cerealis izolatlarına karşı fungisit direnci riskini değerlendirmek için yapmış olduğu çalışmalarında, iprodione' a dayanıklı mutantların ayrıca fludioxonile karşı direnç gösterirken, difenoconazole' a duyarlı olduğunu tespit etmişlerdir. Bizim çalışmamızda da petri çalışmasında patojen gelişimini 1/2000 kat dozda engellediği halde, saksı denemesinde x2 kat dozda fungisit kullanılmasına rağmen kısmen (\% 2030) çökerteni engellediği görülmüştür.

Thack ve ark. (2013) şeker pancarında Ramularia yaprak lekesine karşı yapmış olduğu çalışmalarında epoxiconazole, difenoconazole ve pyraclostrobin kullanımının hastalık gelişimini \%84-100 oranında azalttığını tespit etmişlerdir. Bizim çalışmamızda da patojene karşı Pyraclostrobin+ Epoxiconazole fungisitinin \% 50 etkisi gözlemlenmiştir.

Kataria ve ark. (1991), Rhizoctonia izolatlarına karşı yapmış oldukları çalışmalarında Propiconazole tek başına $R$. zeae ve $R$. oryzae' ye karşı güçlü aktivite gösterirken, $R$. solani' ye daha az etkili bulmuşlardır. Bizde ise Difenoconazole+Propiconazole karışımının patojene karşı etkisi gözlemlenmemiştir. Gerekçe olarakta patojenin \% 100’ lük virülensi ve birim alana düşen yüksek inokulum seviyesi olduğu düşünülebilir.

Sedaxane+Fludioxonil+Metalaxyl-M fungisit karışımı ülkemizde henüz ruhsatlı bir preparat değildir ve almış olduğumuz sonuçlara göre tam dozunda \% 87.5' luk yüksek bir etki ile patojene karşı başarılı olduğu gözlemlenirken, çift kat dozunda bu etki \% 45' lere kadar düşmüştür. Bu miktarın tohum ve yeni çıkan fideler için toksik etkiye sebebiyet vermiş olabileceği düşünülmektedir.

\section{Sonuçlar ve Öneriler}

Virülensliği \% 100 olan multinükleat Rhizoctonia solani patojenine karşı iklim odasında kontrollü şartlarda 8 ayrı fungisitle yapılan çalışmalarda, patojene karşı en etkili fungisitin Azoxystrobin' in çift kat dozu ile Sedaxane+Fludioxonil+Metalaxyl-M fungisit karışımının tam dozu yüksek etkili olarak, Spiroxamine+Prothioconazole, Tolclofos-methyl' in çift kat dozları ve Pyraclostrobin+ Epoxiconazole' ün ise tam dozu \% 50-65 oranında orta etkili fungisitler olarak tespit edilmiştir. Bu sonuçlar 1şı̆̆ında hastalık ile kimyasal mücadelede bu fungisitlerin, patojenin yüksek inokulumuna ve yüksek virülensine rağmen gayet başarılı olduğu tespit edilmiştir. Ayrıca 
yaz dönemi dışında tarla denemelerinde yetersiz güneş ışı̆ğ, patojenin gelişimini yavaşlattığ iç̧in hastalığın seyrinin gerilemesine neden olarak bu nedenle oluşabilecek olumsuz sonuçlara karşı, kontrollü iklim odası çalışmaları hastalıkla mücadelede bir alternatif metot olarak kullanılması uygun olarak kabul edilmiştir.

\section{Teșekkür}

$\mathrm{Bu}$ çalışma, $115 \mathrm{O} 562$ nolu TÜBİTAK projesinde elde edilen bitki örneklerinden ve 18L0447014 nolu Ankara Üniversitesi BAP Projesi ile finanse edilen proje sonuçlarının bir kısmını içermektedir. Yazarlar ayrıca arazi çalışmasına katkıları nedeniyle Torku, Konya Şeker ve Ilgın şeker fabrikalarına; desteklerinden dolayı Dr. Rıza Kaya' ya (Ankara Şeker Enstitüsü), fungisit temininde yardımcı olan Bayer, Agrobest, Syngenta, Sumiagro, AMC ilaç firmalarına teşekkür ederler.

Not: Bu çalışma Meltem AVAN’ in doktora tezinden üretilmiştir.

\section{Kaynaklar}

Alfaig, E. A. A., Suleimain, K. H., and Elhaj, A. M. (2011). J. Sci Tech., 12(2), 1-6.

Anderson, N. A. (1982). Genetics and pathology of Rhizoctonia solani. The Annual Review of Phytopathology, 20, 329-347.

Arabiat, S., and Khan, M. F. (2016). Sensitivity of Rhizoctonia solani AG-2-2 from Sugar Beet to Fungicides. Plant disease, 100(12), 2427-2433.

Bolton, M. D., Panella, L., Campbell, L., and Khan, M. F. (2010). Temperature, moisture, and fungicide effects in managing Rhizoctonia root and crown rot of sugar beet. Phytopathology, 100(7), 689-697.

Buhre, C., Kluth, C., Bürcky, K., Märländer, B., and Varrelmann, M. (2009). Integrated control of root and crown rot in sugar beet: Combined effects of cultivar, crop rotation, and soil tillage. Plant Disease, 93(2), 155-161.

Büttner, G., Pfähler, B., and Märländer, B. (2004). Greenhouse and field techniques for testing sugar beet for resistance to Rhizoctonia root and crown rot. Plant breeding, 123(2), 158-166.

Carling, D. E., Rothrock, C. S., MacNish, G. C., Sweetingham, M. W., Brainard, K. A., and Winters, S.W. (1994). Characterization of anastomosis group 11 (AG-11) of Rhizoctonia solani. Phytopathology, 84, 1387-1393.

Cotterill, P. J., Ballinger, D. J., and Kollmorgen, J. F. (1989). Use of three screening techniques for the evaluation of fungicides to control Rhizoctonia root rot of wheat. Annals of applied biology, 115(2), 229-235.

Djébali, N., Elkahoui, S., Taamalli, W., Hessini, K., Tarhouni, B., and Mrabet, M. (2014). Tunisian Rhizoctonia solani AG3 strains affect potato shoot macronutrients content, infect faba bean plants and show in vitro resistance to azoxystrobin. Australasian Plant Pathology, 43(3), 347-358.

Draycott, A. P. (2006). Introduction, pp. 1-8. In: DRAYCOTT A.P. (eds.) Sugar Beet. Blackwell, Oxford, United Kingdom.

Engelkes, C. A., and Windels, C. E. (1996). Susceptibility of sugarbeet and beans to Rhizoctonia solani AG 2-2 IIIB and AG 2-2 IV. Plant Disease, 80, 1413-1417.

FAOSTAT, (2019). Food and Agriculture Organization of the United Nations [online]. Website http://www.fao.org/faostat/en/\#data/QC/visualize (accessed on 12.12.2019). 
Hamada, M. S., Yin, Y., and Ma, Z. (2011). Sensitivity to iprodione, difenoconazole and fludioxonil of Rhizoctonia cerealis isolates collected from wheat in China. Crop protection, 30(8), 1028-1033.

Harveson, R. M. (2008). Rhizoctonia root and crown rot of sugar beet. Univ. Nebr. Ext. Publ. G1841.

Harveson, R. M., Hanson, L. E., and Hein, G. L. (2009). Compendium of Beet Disease and Pests. The American Phytopathological Society Press, St. Paul, MN.

Herr, L. J., and Roberts, D. L. (1980). Characterization of Rhizoctonia populations obtained from sugarbeet fields with differing soil textures. Phytopathology, 70(6), 476-480.

Karman, M. (1971). Denemelerin Kuruluşu ve Değerlendirme Esasları. T.C. Tarım Bakanlığı Zirai Mücadele ve Karantina Genel Müdürlüğ̈̈ Yayınları, 279s.

Kataria, H. R., Singh, H., and Gisi, U. (1989). Interactions of fungicide-insecticide combinations against Rhizoctonia solani in vitro and in soil. Crop Protection, 8(6), 399-404.

Kataria, H. R., Hugelshofer, U., and Gisi, U. (1991). Sensitivity of Rhizoctonia species to different fungicides. Plant Pathology, 40(2), 203-211.

Khan, M. F. R., and Carlson, A. (2009). Efficacy of fungicides for controlling Cercospora leaf spot on sugarbeet. Sugarbeet Research and Extension Reports, 39, 216-219.

Larkin, R. P., Roberts, D. P., and Gracia-Garza, J. A. (1998). Biological control of fungal diseases. In: Fungicidal activity, chemical and biological approaches. NY: Wiley, New York, USA. pp: 141-191.

Long, L. X. L. J. Z., and Xiaolin, L. J. L. (2001). Effect of fungicides and its mixture on the toxicity and morphology of the Rhizoctonia solani of rice. Journal of Plant Protection, (4), 12.

Ogoshi A. (1987). Ecology and pathogenicity of anastomosis and intraspecific groups of Rhizoctonia solani Kühn. Annual Review of Phytopathology, 25, 125-143.

Panella, L. W., Ruppel, E. G., Hecker, R. J., Johnson, J. W., Buntin, G. D., Cunfer, B. $\quad$ M., ... and Martin, T. J. (1995). 2311501. Registration of four multigerm sugarbeet germplasms resistant to Rhizoctonia root rot: FC716, FC717, FC718, and FC719. Crop science, 35(1), 291-292.

Schmitthenner, A. F., and Hilty, J. W. (1962). A method for studying postemergence seedling root rot. Phytopathology, 52, 177-179.

Sneh, B., Burpee L., and Ogoshi A. (1991). Identification of Rhizoctonia Species. APS Press, St. Paul Minnesota, 135 pgs.

Thach, T., Munk, L., Hansen, A. L., and Jørgensen, L. N. (2013). Disease variation and chemical control of Ramularia leaf spot in sugar beet. Crop protection, 51, 68-76.

TÜIK, (2019). Türkiye İstatistik Kurumu. https://biruni.tuik.gov.tr/medas/ ?kn=92\& locale=tr (Accesssed on 12.12.2019).

Windels, C. E., and Brantner, J. R. (2005). Early-season application of azoxystrobin to sugarbeet for control of Rhizoctonia solani AG 4 and AG 2-2. Journal Sugar Beet Research, 42, 1-17.

Zhao, C., Li, Y., Wu, S., Wang, P., Han, C., and Wu, X. (2019). Anastomosis group and pathogenicity of Rhizoctonia spp. associated with seedling damping-off of sugar beet in China. European journal of plant pathology, 153(3), 869-878. 